\title{
Tumor angiogenesis and anti-angiogenic gene therapy for cancer (Review)
}

\author{
TINGLU LI ${ }^{1-3 *}$, GUANGBO KANG ${ }^{1-3^{*}}$, TINGYUE WANG ${ }^{1-3}$ and HE HUANG ${ }^{1-3}$ \\ ${ }^{1}$ Department of Biochemical Engineering, School of Chemical Engineering and Technology, \\ Tianjin University; ${ }^{2}$ Key Laboratory of Systems Bioengineering, Ministry of Education, Tianjin University; \\ ${ }^{3}$ Collaborative Innovation Center of Chemical Science and Engineering, Tianjin 300072, P.R. China
}

Received January 11, 2016; Accepted July 11, 2017

DOI: $10.3892 / \mathrm{ol} .2018 .8733$

\begin{abstract}
When Folkman first suggested a theory about the association between angiogenesis and tumor growth in 1971, the hypothesis of targeting angiogenesis to treat cancer was formed. Since then, various studies conducted across the world have additionally confirmed the theory of Folkman, and numerous efforts have been made to explore the possibilities of curing cancer by targeting angiogenesis. Among them, anti-angiogenic gene therapy has received attention due to its apparent advantages. Although specific problems remain prior to cancer being fully curable using anti-angiogenic gene therapy, several methods have been explored, and progress has been made in pre-clinical and clinical settings over previous decades. The present review aimed to provide up-to-date information concerning tumor angiogenesis and gene delivery systems in anti-angiogenic gene therapy, with a focus on recent developments in the study and application of the most commonly studied and newly identified anti-angiogenic candidates for anti-angiogenesis gene therapy, including interleukin-12, angiostatin, endostatin, tumstatin, anti-angiogenic metargidin peptide and endoglin silencing.
\end{abstract}

\section{Contents}

1. Introduction

2. Gene therapy

3. Delivery systems for gene therapy

4. Anti-angiogenesis gene therapy and angiogenesis inhibitors

5. Conclusion and future direction

Correspondence to: Dr He Huang, Department of Biochemical Engineering, School of Chemical Engineering and Technology, Tianjin University, 92 Weijin Road, Tianjin 300072, P.R. China E-mail: huang@tju.edu.cn

*Contributed equally

Key words: tumor angiogenesis, gene therapy, angiogenesis inhibitor, interleukin-12, angiostatin, endostatin, endoglin silencing

\section{Introduction}

Angiogenesis is a complex multi-step process. Angiogenesis is a biological process in which novel capillary blood vessels grow from pre-existing vasculature (1), providing tissues with oxygen and nutrients. As it is correlated with numerous complicated interactions between various biological components, such as several cell types, soluble angiogenic factors and extracellular matrix components, the process of angiogenesis is complex, and primarily consists of four distinct sequential steps: i) Degradation of basement membrane glycoproteins and other components of the extracellular matrix surrounding the blood vessels by proteolytic enzymes; ii) endothelial cell activation and migration; iii) endothelial cell proliferation; and iv) endothelial cells transforming into tube-like structures and forming capillary tubes, and developing into novel basement membranes (2). In normal conditions, angiogenesis only occurs during embryonic development, the female reproductive cycle and wound repair (3). However, aberrant angiogenesis is a key mediator and a major process in cancer development.

Tumor angiogenesis. In 1971, Folkman (4) suggested the hypotheses that angiogenesis is required for the development and growth of solid tumors beyond the size of $1-2 \mathrm{~mm}^{3}$. Subsequently, they showed specific fragmentary evidence to indicate that solid tumors were dependent upon neovascularization for sustained growth (5). Following this, an anti-angiogenic strategy, which may develop into a novel therapeutic approach for the treatment of solid tumors, has become a focus of study groups. Over the previous 40 years, a vast volume of data has accumulated, supporting Folkman's hypothesis (6). Concurrently, the intricate mechanism of tumor angiogenesis has been gradually exposed as efforts have been put into this field of study. The normal process of angiogenesis is under a relatively dynamic homeostasis, tightly controlled by pro-angiogenic and anti-angiogenic regulators. Once this homeostasis is disrupted, the 'angiogenic switch', which refers to the phenotype, will become active and initiate angiogenesis (7).

Through numerous studies investigating tumor angiogenesis, different types of regulators have been defined (8-13). These regulators are separately released from endothelial cells, tumor cells, stromal cells, blood and the extracellular 
matrix (14-17). These modes of tumor angiogenesis may coexist or shift from one to another during tumor growth and proliferation (18-20). Certain well-known pro-angiogenic regulators include vascular endothelial growth factor (VEGF), basic fibroblast growth factor, transforming growth factor- $\alpha$ and $-\beta$ (TGF- $\alpha$ and $-\beta$ ), epidermal growth factor, platelet-derived growth factor, placental-derived growth factor and angiopoietin 1 and 2 . Specific, commonly studied anti-angiogenic regulators include angiostatin, endostatin, tumstatin, platelet factor-4, interleukin (IL)-12, thrombospondin-1 (TSP-1), tissue inhibitors of metalloproteinases (TIMPs) and interferon- $\alpha$, $-\beta$ and $-\gamma$. Various biological activities trigger this angiogenic switch. Genetic mutations (activation of oncogenes or loss of tumor-suppressor genes that control production of angiogenesis regulators), metabolic stress (hypoxia, low $\mathrm{pH}$ or hypoglycemia), mechanical stress (pressure generated by proliferating cells) and the immune/inflammatory response (immune/inflammatory cells that have infiltrated the tissue) are important stimuli of angiogenic signaling and tend to cause tumor formation $(21,22)$. Among them, hypoxia is one of the primary factors that drive tumor angiogenesis, causing increased expression of VEGF and other angiogenesis stimulators from hypoxic cells (23). Concurrently, matrix-remodeling enzymes, particularly matrix metalloproteinases, mediate a number of the changes in the microenvironment of the tumor tissue by degrading the extracellular matrix (24). Once hypoxia induces the upregulation of VEGF, angiogenesis is initiated with additional activation of hypoxia-inducible factor (HIF) signaling, to provide oxygen supply (25), which stimulates the endothelial cells (ECs) of the preexisting vasculature to sprout and migrate into the hypoxic tissue, led by a gradient of VEGF (26). Subsequently, the endothelial cells differentiate into several cell types, consisting of the tip, stalk and tube cells (27). The tip cells, which express delta-like 4 (DLL4), are non-proliferative cells located at the top of the novel vessels and guide the direction of the novel vessel in response to VEGF signals $(28,29)$. The stalk cells, which express Notch-1, are highly proliferative, with the ability to elongate the sprouting vessel through proliferation when they receive DLL4/Notch signaling (30). The tube cells are non-proliferating, which shape the final appearance of the vessels (6). During additional vascular formation, endothelial progenitor cells (EPCs) are involved in the construction of the inner layer of the novel blood vessels, with pericytes such as specialized muscle cells stabilizing the vessel tubes by providing structural support and forming an outer layer around the ECs (31,32). Subsequently, the ECs connect with each other to form a continuous endothelium, which is characterized by complex, tight junctions (32) and create loops that allow the blood to circulate through adhesion molecules, followed by the construction of the basement membrane. Finally, the vessel is mature and capable of transporting oxygen and nutrition to meet the requirements of the hypoxic tumor tissues (33).

\section{Gene therapy}

Gene therapy is a therapeutic technique used to correct or alleviate the symptoms of disease by transferring the exogenous genes into the cells of an individual, which may supplement or alter a defective gene, or induce cell death. In total, there are 4 major strategies exploited in gene therapy, consisting of: Gene replacement; gene modification; gene augmentation; and gene blockage (34). By July 2015, >2,200 clinical trials on gene therapy had been conducted or approved worldwide (35-37). Among these trials, $>60 \%$ are associated with cancer gene therapy, indicating that gene therapy is not limited to hereditary diseases, but may be used for acquired diseases such as cancer, and it has already become a promising approach in cancer therapy.

In previous years, various gene therapy strategies for cancer have been developed, such as anti-angiogenic gene therapy, suicide gene therapy, immunomodulatory gene therapy, siRNA therapy, pro-apoptotic gene therapy and oncolytic gene therapy $(38,39)$. However, as tumorigenesis is an intricate process that involves various signaling pathways and different mechanisms, and often a single gene may evoke several biological processes and activate diverse signaling pathways, occasionally there is no explicit boundary between these aforementioned gene therapies. For example, gene tumor protein p53 may not only elicit apoptotic activities in tumor cells (40-42), but also has demonstrated anti-angiogenic efficacy in a number of studies $(43,44)$. Therefore, gene therapy exploiting the p53 gene may be characterized as an anti-angiogenic and pro-apoptotic therapy.

Generally, whether gene therapy may be implemented successfully or not will depend on two conditions: i) A suitable gene must be identified to relieve the disease symptoms; and ii) this gene must be delivered to the right location for the gene expression product to treat the disease without causing side effects. As gene therapy is such a precise and delicate therapeutic intervention at the molecular level, there remain a number of technical difficulties to overcome, one being the ability to develop a suitable delivery system for the gene therapy.

\section{Delivery systems for gene therapy}

Constructing an efficient, safe and specific delivery system is the fundamental basis for gene therapy. Ideal gene delivery systems should possess several attributes: i) A relatively broad range of insertion capacity, with high transfection rates and a non-invasive administration method; ii) it allows for sustained gene expression; iii) a good target-specific selectivity for the tumor type; iv) safety-associated features, including biocompatibility, stability and non-immunogenicity; v) easy availability. At present, numerous different vectors have been constructed and applied in clinical trials: Table I has listed the top 10 most used vectors in clinical studies (35-37). Generally, the delivery systems in gene therapy may be categorized into two groups, namely viral and non-viral vectors systems (45).

Viral vectors. Viral vectors were the first studied and are the most commonly applied gene delivery systems, as they are derived from viruses with a natural ability to transfection (46). In order to make viral vectors more suitable for delivering heterologous genes into targeted cells, they are often genetically optimized for improved efficiency, increased safety and enhanced uptake $(46,47)$. During previous decades, the understanding of viral vectors has increased, concomitant with improvement in their design and production. Based on 
Table I. Top 10 most used vectors in gene therapy clinical trials.

\begin{tabular}{|c|c|c|c|c|}
\hline Vectors & Advantages & Disadvantages & $\begin{array}{l}\text { Number } \\
\text { of } \\
\text { clinical } \\
\text { trials }\end{array}$ & $\begin{array}{l}\text { Proportion } \\
\text { in the total } \\
\text { clinical } \\
\text { trials } \%\end{array}$ \\
\hline Adenovirus & $\begin{array}{l}\text { High efficiency in transfection and } \\
\text { transgene expression; ability to } \\
\text { transfect a broad spectrum of cell types; } \\
\text { independent of active cell division; } \\
\text { high titers; does not integrate into } \\
\text { host DNA }\end{array}$ & $\begin{array}{l}\text { Expression is transient } \\
\text { and the vector itself will } \\
\text { elicit inflammatory and } \\
\text { immune response }\end{array}$ & 503 & 22.2 \\
\hline Retrovirus & $\begin{array}{l}\text { Transduces a broad range of cells; } \\
\text { allows a sustainable and stable } \\
\text { expression of genes up to } 12 \mathrm{~kb} \text {; } \\
\text { high titers }\end{array}$ & $\begin{array}{l}\text { Requires cell division for } \\
\text { successful transduction; } \\
\text { no targeting ability and } \\
\text { specificity }\end{array}$ & 417 & 18.9 \\
\hline Plasmid DNA & $\begin{array}{l}\text { Low production cost; } \\
\text { easy to manufacture; } \\
\text { higher transfection rate } \\
\text { mediated by electroporation } \\
\text { or ultrasound }\end{array}$ & $\begin{array}{l}\text { Naked plasmid only transfects } \\
\text { muscle cells; susceptible to } \\
\text { enzymatic degradation }\end{array}$ & 397 & 17.9 \\
\hline $\begin{array}{l}\text { Adeno-associated } \\
\text { virus }\end{array}$ & $\begin{array}{l}\text { High efficiency in transfection } \\
\text { and transgene expression; } \\
\text { replication defective; } \\
\text { easily transduced }\end{array}$ & $\begin{array}{l}\text { Integrates into the host-cell } \\
\text { genome; only allows a gene } \\
\text { insert up to } \sim 5 \mathrm{~kb}\end{array}$ & 137 & 6.2 \\
\hline Vaccinia virus & $\begin{array}{l}\text { Self-replicating; tumor-selective; } \\
\text { effective in apoptosis-defective cells }\end{array}$ & High immunogenicity & 121 & 5.5 \\
\hline Lipofection & $\begin{array}{l}\text { Selective targeting ability toward } \\
\text { angiogenic endothelial cells; easier } \\
\text { to manufacture, purify, chemically } \\
\text { modify and scale-up than viral vectors } \\
\text { and bacterial vectors; increased gene } \\
\text { transfection compared with naked } \\
\text { plasmid DNA }\end{array}$ & $\begin{array}{l}\text { Toxicity; non-uniformity } \\
\text { in targeting tumor } \\
\text { vasculature }\end{array}$ & 115 & 5.2 \\
\hline Lentivirus & $\begin{array}{l}\text { Transduces both proliferating and } \\
\text { non-proliferating cells; prolonged } \\
\text { transgene expression with a maximum } \\
8 \mathrm{~kb} \text { gene insertion }\end{array}$ & $\begin{array}{l}\text { Risk of viral infection and } \\
\text { insertional mutagenesis }\end{array}$ & 114 & 5.2 \\
\hline Poxvirus & $\begin{array}{l}\text { Broad spectrum host range of infection; } \\
\text { no integration into host genome; } \\
\text { high efficiency of gene transfection } \\
\text { and expression }\end{array}$ & High Immunogenicity & 101 & 4.6 \\
\hline $\begin{array}{l}\text { Herpes simplex } \\
\text { virus }\end{array}$ & $\begin{array}{l}\text { Highly efficient in transduction } \\
\text { and gene expression; allows } \\
\text { gene inserts } \geq 50 \mathrm{~kb}\end{array}$ & $\begin{array}{l}\text { No cell targeting specificity; } \\
\text { transient transgene expression; } \\
\text { cytotoxic to host cells }\end{array}$ & 73 & 3.3 \\
\hline RNA transfer & $\begin{array}{l}\text { Various ways to transfer, } \\
\text { including using cationic polymers, } \\
\text { cationic lipids, carbon nanotubes and } \\
\text { cell penetrating peptides }\end{array}$ & $\begin{array}{l}\text { Hard to condense; low } \\
\text { transfection efficiency }\end{array}$ & 39 & 1.8 \\
\hline
\end{tabular}

Source: (16-18).

this progress, a number of viral vectors have been identified and explored for gene delivery, including commonly used viral vectors, such as adenovirus, adeno-associated virus (AAV), retrovirus, herpes simplex virus (HSV), lentivirus, and poxvirus (45), and certain novel developed viral vectors, such as alphavirus vectors (48). Among these, lentiviral vectors and AAV vectors have been the subject of focus in previous years (20), and a recent patent has provided novel methods to 
shield the lentiviral vectors with a thin polymer shell, conferring the shielded virus novel binding ability with additional characteristics, including higher thermal stability, resistance to serum inactivation and the ability to infect cells with high efficiency (49). Generally, compared with traditional transfection methods, viral vectors confer a higher transduction efficiency with long-term gene expression. However, certain weaknesses exist in terms of the immunogenicity, mutagenicity, toxicity and high cost of these vectors and the limited size of the transfected gene (50). Therefore, additional studies are required for optimal use of viral vectors in gene therapy.

Non-viral vectors. In order to circumvent the limitations of viral vectors, there has been a focus on developing non-virus-mediated gene delivery modalities, including physical mediated methods, and chemical and biological vectors. Physical methods primarily consist of microinjection, microparticle bombardment, ultrasound mediated microbubble and electroporation. Compare with viral vectors, ultrasound-targeted microbubbles $(51,52)$ and gene electrotransfer plasmids $(53)$ have received the majority of the attention in previous years as they are more safe and efficient in terms of gene delivery. Commonly used chemical vectors may be classified into 2 major types based on the nature of the synthetic material, namely cationic polymers and cationic liposomes (45). Despite the promising prospect that cationic liposomes presented with several studies in clinical trials, the low transfection efficiency and side effects, including toxicity, are the primary obstacles preventing its widespread use (54-57). Therefore, the newly-described cationic core, the shell nanoparticles, appears to be an alternative to liposomes, as it offers a greater number of advantages, including high gene transfection efficiency and the ability of the concurrent delivery of drugs and genes to the same cells (58). Biological vectors generally refer to bacteria and specific mammalian cells. The types of bacteria used as vectors include attenuated strains of Bifidobacteria, Clostridia, Listeria, Salmonella, Shigella, Yersinia and non-pathogenic Escherichia coli (34). As for mammalian cells, hematological cells and mesenchymal stem cells (MSCs) are usually used as carriers of gene therapy vectors (59). Additionally, gene-transfected EPCs may be useful as a tumor-specific drug delivery system (60). Compared with viral vectors, non-viral vectors provide advantages, including relative safety, ability to transfer large size genes and less toxicity. They may also be constructed and modified by simple methods for tissue- or cell-specific targeting (54). However, non-viral vectors exhibit limitations of a low transfection efficiency and poor transgene expression (61). In conclusion, all of these methods have been investigated and each of them presents distinct advantages and disadvantages.

\section{Anti-angiogenesis gene therapy and angiogenesis inhibitors}

Anti-angiogenic gene therapy targeting endothelial cells $(E C s)$. For the majority of cancer therapy strategies, the tumor vasculature has provided issues for drug delivery, as it is a barrier that prevents drugs from reaching tumor cells. However, tumor angiogenesis is an easily accessible target for anti-angiogenic cancer therapy, particularly when the anti-angiogenic drugs are administered by delivery systems with specificity for tumor endothelial cells. Notably, compared with the anti-angiogenic therapies directly targeting tumor cells, targeting ECs may be more practical when compared with tumor cells, as endothelial cells have been identified to be genetically more stable (62). The inhibition of EC proliferation, migration and EC apoptosis by anti-angiogenic agents may damage the viability of numerous tumor cells, due to destruction of ECs not only limiting the supply of oxygen, nutrients and growth factors produced by ECs to the surrounding tumor cells, but also leading to the lack of structural support for tumor cells, eventually resulting in the disassembly of tumor tissues (Fig. 1). In addition, the same anti-angiogenic molecule may be efficient in various types of cancer (63). Based on those therapeutic advantages, efforts have been made to explore tumor treatments that target angiogenesis. Furthermore, the comprehensive study of various angiogenesis growth factors and inhibitors with demonstrated therapeutic effects as administered anti-angiogenic drugs have provided evidence for anti-angiogenesis therapy. Table II summarizes the anti-angiogenic drugs approved for clinical use. However, during the long-term process of cancer treatment, the efficacy of pharmaceutical proteins is limited due to their short half-life, high cost and vulnerability to interference by endogenous substances (64). Compared with monoclonal antibodies and engineered antibodies, gene therapy has the advantages of sustained and localized expression of the therapeutic gene product, lower cost and fewer side effects $(65,66)$. Therefore, anti-angiogenesis cancer gene therapy and combination of gene and anti-angiogenesis therapy have become required.

Principles of anti-angiogenic gene therapy. At present, anti-angiogenic cancer gene therapies primarily adopt the following two principles: Gene augmentation; and gene blockade. The former involves introducing exogenous anti-angiogenic genes into targeted cells so that through their expression tumor angiogenesis is halted, while the latter results in the inhibition of the excessive expression of pro-angiogenic genes in endothelial cells, and other tissue cells, of the tumor. Therefore, the genes of interest may be divided into equivalent categories: Anti-angiogenic genes utilized for gene augmentation; and pro-angiogenic genes for gene blockade (Fig. 2).

Angiogenesis inhibitors. With the development of biotechnology and an improved understanding of angiogenesis mechanisms, numerous pro- and anti-angiogenesis genes have been identified and utilized in studies investigating cancer gene therapy $(63,67)$. In total, $>300$ angiogenesis inhibitors have been identified at present (68); among them, $>30$ agents have been extensively studied in gene therapy (Table III). As various papers have already reviewed a number of these anti-angiogenic molecules $(63,64,68,69)$, only the most commonly discussed inhibitors will be examined in this paper, to avoid repetition.

IL-12. IL-12, first recognized as a pro-inflammatory cytokine with immunoregulatory functions $(70,71)$, has been suggested to exert an anti-angiogenesis effect in several experiments (72-74). Due to its ability to stimulate immunity and inhibit tumor angiogenesis, IL-12 has been identified as one 


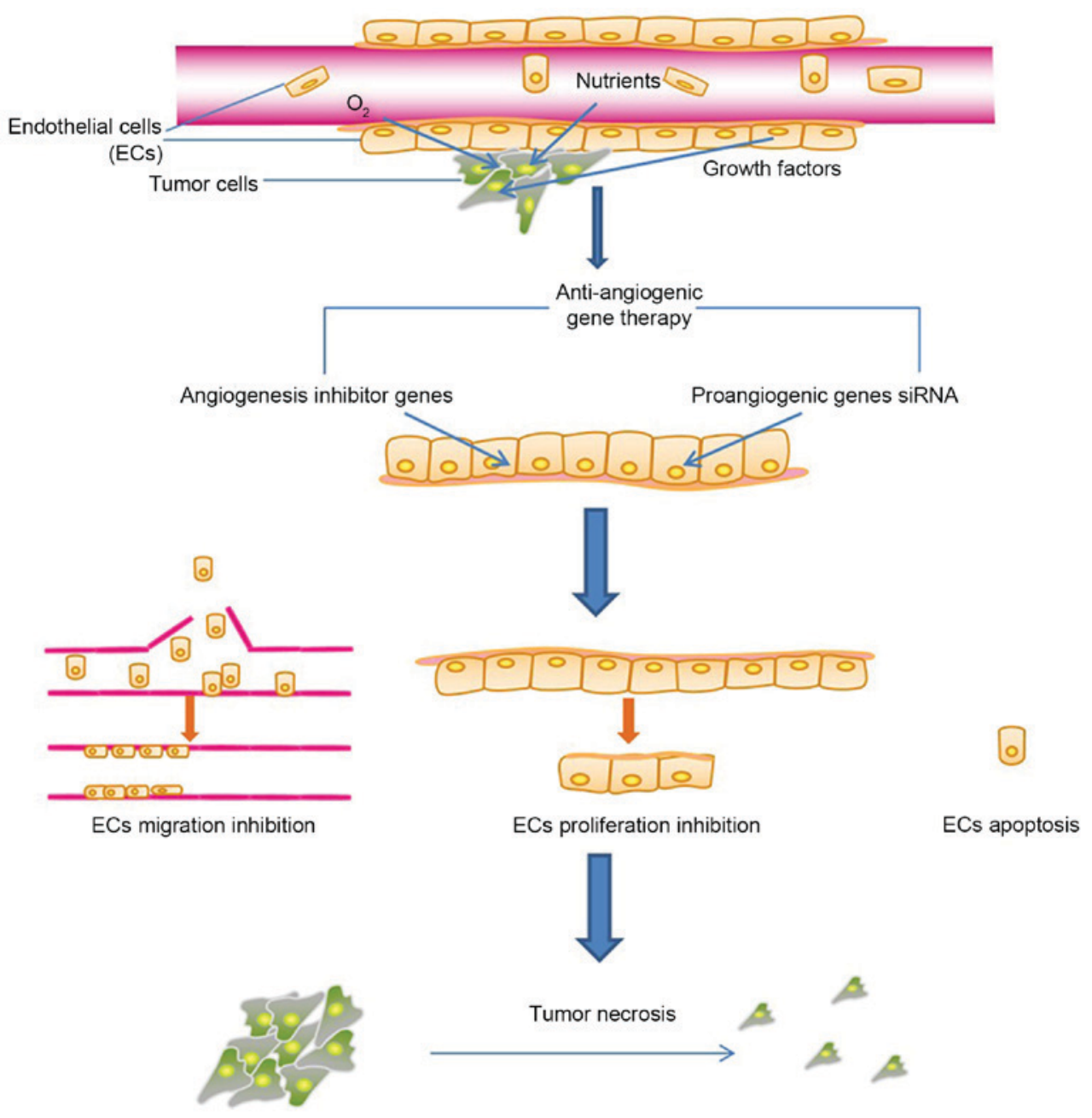

Figure 1. Gene therapy targeting angiogenesis in ECs. The figure depicts the advantages of gene therapy targeting angiogenesis in ECs, as a single vessel may support the growth of numerous tumor cells by providing them with oxygen, nutrients and growth factors produced by surrounding ECs. The inhibition of EC proliferation, migration, and an increase in EC apoptosis by anti-angiogenic agents may lead to the destruction of blood vessels, which may additionally initiate tumor necrosis. ECs, endothelial cells.

of the most potent antitumor candidates not only for cancer immunotherapy (75), but also for anti-angiogenic therapy (76). Although previous evidence has indicated its anti-tumor activities in in vitro and in vivo experiments (77), the anti-tumor effect of IL-12 evidently varies between mouse strains (78), and the mechanism that leads to the various responses remains unclear. However, a previous study demonstrated that the higher expression of IL-12 receptor (IL-12RB1) by C3H/HeJ mouse splenocytes resulted in a significantly stronger response to IL-12 compared with other mouse strains, providing a potential explanation for the variation of IL-12 anti-tumor efficacy between different individuals (78). Although unsatisfactory side effects, including toxicity, have been identified in several early clinical trials using systemically delivered recombinant human IL-12 (rhIL-12) (79-81), interests in gene therapy approaches have increased due to its potential in achieving high drug concentrations in the local tumor environment, with low systemic levels. Apart from several early clinical trials of gene therapy using IL-12 in previous decades, a more recent study provided long-term overall survival results from a phase I study of intratumoral electroporation (EP) of plasmid (p)IL-12, which was completed in 24 patients with malignant melanoma. This study suggested that improved survival is correlated with systemic disease stabilization with pIL-12 EP (82). An additional biomarker analysis study investigating the efficacy of intratumoral electroporation of pIL-12 from a phase 2 study in melanoma also demonstrated that pIL-12 EP monotherapy induces tumor responses in $31 \%$ of patients, and no severe local or systemic toxicity was observed in the treatment (83). Concurrently, certain gene therapies involving IL-12 use different delivery systems to explore therapeutic methods with low systematic toxicities, high tumorous specificities and sustained local expression of IL-12, such as plasmid $(84,85)$, HSV-1 (86), Semliki forest virus vector (87), T-cells (88), a novel helper-dependent adenoviral vector (89) and Lactococcus lactis (90). Other strategies in previous studies have focused on combining IL-12 with other anti-tumor genes, including suicide genes (91), or other therapies, such as chemotherapy (92), to explore its preclinical efficacy and safety prior entry of these methods into clinical trials.

Melanoma differentiation-associated gene-7 (MDA-7). MDA-7, also termed IL-24, was identified through subtraction hybridization from a human melanoma cell line (93), and has demonstrated efficacy as a potent tumor suppressor gene in initial studies in the 1990s (93-95). As an anti-cancer 
Table II. List of antiangiogenic drugs approved for clinical use.

\begin{tabular}{|c|c|c|c|}
\hline Drug & Target/mechanism & Type of cancer & (Refs.) \\
\hline Avastin (Bevacizumab) & $\begin{array}{l}\text { Monoclonal antibody targeting } \\
\text { VEGF }\end{array}$ & $\begin{array}{l}\text { Ovarian, colorectal, renal, breast } \\
\text { and prostate cancers, NSCLC } \\
\text { and glioblastoma }\end{array}$ & $(172-175)$ \\
\hline EYLEA (Aflibercept) & $\begin{array}{l}\text { Fused protein consists of VEGFR1 } \\
\text { and VEGFR2 }\end{array}$ & $\begin{array}{l}\text { Colorectal cancer, prostate cancer, } \\
\text { NSCLC and SCLC }\end{array}$ & $(176-179)$ \\
\hline Erbitux (Cetuximab) & EGFR monoclonal antibody & $\begin{array}{l}\text { Colorectal cancer, gastric cancer } \\
\text { and NHSCC }\end{array}$ & $(180-183)$ \\
\hline Endostar (endostatin) & $\begin{array}{l}\text { Recombinant protein of the } \\
\text { angiogenesis inhibitor endostatin }\end{array}$ & $\begin{array}{l}\text { NSCLC, melanoma, } \\
\text { nasopharyngeal carcinoma } \\
\text { and colorectal cancer }\end{array}$ & $(184-187)$ \\
\hline Nexavar (Sorafenib) & $\begin{array}{l}\text { Molecular inhibitor of VEGFR, } \\
\text { PDGFR and Raf kinases }\end{array}$ & $\begin{array}{l}\text { Hepatocellular carcinoma, } \\
\text { thyroid cancer, ovarian cancer } \\
\text { and renal cancer }\end{array}$ & $(188-191)$ \\
\hline $\begin{array}{l}\text { Sunitinib } \\
\text { (Sutent/SUNITINIB } \\
\text { MALATE) }\end{array}$ & $\begin{array}{l}\text { Molecular receptor tyrosine } \\
\text { kinase inhibitors }\end{array}$ & $\begin{array}{l}\text { Renal cancer, NSCLC, } \\
\text { hepatocellular carcinoma } \\
\text { and prostate cancer }\end{array}$ & $(192-195)$ \\
\hline Sprycel (Dasatinib) & $\begin{array}{l}\text { Multi-BCR/ABL and Src family } \\
\text { tyrosine kinase inhibitor }\end{array}$ & $\begin{array}{l}\text { Chronic myeloid leukemia, } \\
\text { melanoma and adenoid } \\
\text { cystic carcinoma }\end{array}$ & $(196-198)$ \\
\hline Iressa (gefitinib) & EGFR tyrosine kinase inhibitor & $\begin{array}{l}\text { NSCLC, squamous cell carcinoma } \\
\text { of the head and neck, and } \\
\text { esophageal cancer }\end{array}$ & $(199-201)$ \\
\hline Tarceva (Erlotinib) & EGFR tyrosine kinase inhibitor & $\begin{array}{l}\text { Hepatocellular carcinoma, } \\
\text { pancreatic cancer and NSCLC }\end{array}$ & $(188,202-203)$ \\
\hline Votrient (pazopanib) & $\begin{array}{l}\text { RTK inhibitor targeting } \\
\text { VEGFR, PDGFR and c-Kit }\end{array}$ & $\begin{array}{l}\text { Renal cancer, soft-tissue sarcoma, } \\
\text { ovarian cancer and thyroid carcinoma }\end{array}$ & $(204-206)$ \\
\hline
\end{tabular}

VEGF, vascular endothelial growth factor; VEGFR, vascular endothelial growth factor receptor; EGFR, epidermal growth factor receptor; PDGFR, platelet-derived growth factor receptor; RTK, receptor tyrosine kinase; NSCLC, non-small cell lung cancer; SCLC, small cell lung cancer.

agent, MDA-7 functions through diverse modalities, including anti-angiogenesis (96), tumor-specific apoptosis (97) and immunotherapeutic activity (98). Previously, a study examining the effect of MDA-7 on Her2/Neu-induced mammary tumors concluded that MDA-7 inhibited tumor growth of HER2+ breast cancer cells partially through p53 apoptosis effector related to PMP-22, which is a member of the PMP-22 family, with growth arrest and apoptosis-inducing capacities (99). In an additional study, the human MDA-7 gene was transfected into the human laryngeal cancer Hep-2 cell line and human umbilical vein endothelial cells with adenovirus vector (100), and the results demonstrated that MDA-7 exerted anti-tumor functions in the laryngeal carcinoma cell lines, whereas no harmful effect was observed in the healthy cells. As for gene delivery, a study has introduced a method for increasing the expression level of MDA-7 in osteosarcoma (OS) using a novel oncolytic adenovirus, where an increased sensitivity of OS to doxorubicin induced by MDA-7 was also observed (101). Finally, 3 vectors expressing MDA-7 in fusion with the arginine-glycine-aspartic acid (RGD) peptide, which is considered to exhibit the most significant effect on the binding specificity of integrin receptors, were constructed. With a stronger expression potency observed and integrity validated, MDA-7 with RGD peptide appears to be a more appealing therapeutic option, when compared with the administration of MDA-7 alone (102), indicating a future direction for cancer gene therapy.

Angiostatin. Angiostatin is the first of four Kringle domains of a 38-kDa internal proteolytic fragment of plasminogen, which has been recognized as a potent endogenous angiogenesis inhibitor, and its anti-tumor effect has also been widely demonstrated (103). However, the primary obstacle preventing its future application in clinical trials is that it exhibits a limited therapeutic efficacy with a short half-life (104). To resolve this problem, studies have focused on elucidating efficient delivery systems, and experiments investigating various non-viral and viral methods delivering angiostatin gene have been conducted. At present, angiostatin has been expressed in HSV (105,106), vaccinia virus (107), oncolytic measles virus (108), adenovirus (109), adeno-associated viral vectors $(110,111)$ and lentivirus $(112)$, or mediated by plasmids (113) and cationic liposomes (114). Concurrently, angiostatin is often co-transfected with other genes for an enhanced anti-tumor efficacy, like antisense HIF-1 $\alpha$ (115), p53 (116), IL-12 (117), Fas gene (113), soluble form of vascular 


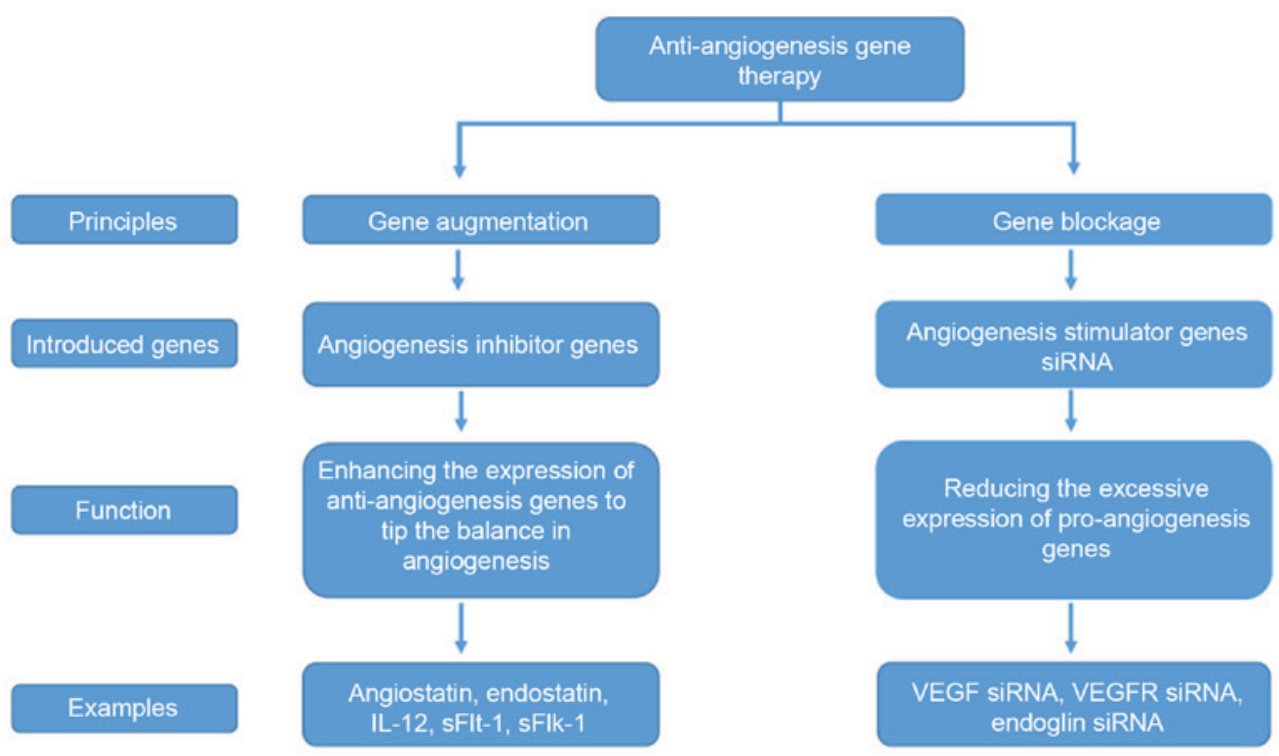

Figure 2. Principles of anti-angiogenesis gene therapy. The flowchart depicts the two major principles of anti-angiogenic gene therapy. It highlights the major differences between the principles, and indicates representative examples in each category. IL-12, interleukin 12; sFlt-1, soluble fms-like tyrosine kinase-1; sFlk-1, soluble form of vascular endothelial growth factor receptor 2; VEGF, vascular endothelial growth factor, siRNA, small interfering RNA; VEGFR, VEGF receptor.

endothelial growth factor receptor 2 sFlk1 (112) and most commonly used endostatin-angiostatin fusion gene due to the fact that they were identified to act synergistically when used in combination (106-108). Previous studies (118-120) suggested that angiostatin mimic (kringle1-5) appears more attractive compared with angiostatin in terms of tumor suppression and metastasis inhibition, potentially due to the synergistic effect of the Kringle 5 domain of plasminogen.

Endostatin. Endostatin, a $20 \mathrm{kDa}$ C-terminal cleavage fragment from the $\alpha 1$ chain of type XVIII collagen, is one of the most extensively studied endogenous angiogenesis inhibitor that was originally identified by O'Reilly $(121,122)$. Endostar (YH-16), a protein drug of recombinant human endostatin, was approved by China's State Food and Drug Administration for the treatment of non-small cell lung cancer in 2005 (123), indicating the potential of endostatin in cancer treatment. A gene-based endostatin approach has also received attention, and has made its progression within a pre-clinical context over previous decades, along with breakthroughs in clinical trials. Previous studies primarily focused on two categories: The joint method, combining endostatin with other genes or with other cancer therapeutics; and the exploration of a more suitable delivery system for endostatin to be expressed in a more efficacious, tumor-targeted way. For example, Huiqi et al (124) examined the therapeutic effect of combining endostatin gene therapy with ${ }^{32} \mathrm{P}$ colloid radiotherapy on hepatocellular carcinoma (HCC) cells, and concluded that the combination of these two treatments demonstrated an improved therapeutic effect on HCC compared with either treatment alone. Kubo et al (112) also investigated a combinatorial anti-angiogenic gene therapy with endostatin, angiostatin and sFlk1, and an improved therapeutic efficacy was demonstrated compared with that of a single-agent regimen, due to the ability of three genes targeting different pathways of endothelial growth factor signaling. An additional study identified that the combination of human endostatin and soluble tumor necrosis factor (TNF)-related apoptosis-inducing ligand gene transfer indicated an enhanced tumor suppressing effect through anti-angiogenic and pro-apoptotic mechanisms (125). As for delivery systems, a previous study has demonstrated that ultrasound-targeted microbubble destruction (UTMD)-mediated gene therapy may enhance the transfection efficiency of endostatin, indicating that the UTMD-mediated delivery system exhibits potential as a gene therapy targeting retinal neovascularization (126). Additionally, certain other previous experiments concerning the efficacy of gene delivery or the efficiency of combinatorial therapy utilizing endostatin have all demonstrated progress in cancer treatment to a certain level (108,127-130).

Tumstatin. As an alternative appealing endogenous angiogenesis inhibitor, tumstatin, a cleavage fragment of the $\alpha 3$ chain of type IV collagen (131), is an exciting candidate for cancer gene therapy, due to the fact that its anti-angiogenic ability is 10-fold higher compared with that of endostatin (132). By binding to $\alpha_{\mathrm{V}} \beta_{3}$ and $\alpha_{3} \beta_{1}$ integrins (133), tumstatin exerts its anti-angiogenic effects through diverse modalities, including the induction of endothelial cells apoptosis, inhibition of cell proliferation and tube formation in endothelial cells, and a previous study has identified that tumstatin stimulates endothelial cell apoptosis through the Fas signaling pathway (134). The anti-angiogenic and anti-tumorigenic effects of tumstatin have been widely demonstrated by gene transfer experiments conducted in various xenograft models, such as hepatocellular carcinoma (135), S180 tumor (136), lung carcinoma (137) and renal carcinoma cell (138). In previous years, efforts have been made to develop and test diverse delivery systems in tumstatin gene therapy. For example, lentivirus-mediated signal peptide TNF- $\alpha$ -Tumstatin (45-132)-expressing mesenchymal stem cells (SPTT-MSCs) have been used as a novel delivery approach in human prostate cancer cells in vitro and in vivo, and 
Table III. Angiogenesis inhibitors for gene therapy.

Angiogenesis inhibitor

Mode of action

16-kDa a prolactin fragment

2-methoxyestradiol

Angiostatin

Antiangiogenic metargidin peptide

Arresten

Canstatin

Cleaved antithrombin III

Endostatin

Endothelial-monocyte activating polypeptide II

\section{HGFK1}

Human ribonuclease inhibitor

IL-12

IL-18

IL-24

Interferon-inducible protein-10

Interferons

Kallistatin

NK4

p53

Pigment epithelium-derived factor

Platelet factor-4

Restin

sFlk-1

sFLT-1

Tetrahydrocortisol

Thrombospondin-1

Tissue inhibitors of metalloproteinases

TNF- $\alpha$

Tumstatin

Vascular endothelial growth inhibitor

Vastatin

Vasostatin

Endoglin siRNA

VEGF SiRNA

VEGFR-2 siRNA

HGF SiRNA

Survivin SiRNA
Inhibits EC proliferation, induces apoptosis

Inhibits angiogenesis by inhibiting hypoxic inducible factor- $1 \alpha$

Inhibits EC proliferation and migration

Inhibits angiogenesis by binding to $\alpha_{5} \beta_{1}$ and $\alpha_{\mathrm{V}} \beta_{3}$ integrins

Inhibits angiogenesis by binding to $\alpha_{1} \beta_{1}$ integrin

Induces proapoptotic activities in EC

Potently inhibits angiogenesis and tumor growth

Inhibits angiogenesis by binding $\alpha_{5} \beta_{1}$ integrin

Inhibits angiogenesis through upregulating TNF receptor-1, induces EC apoptosis

Kringle 1 domain of human hepatocyte growth factor, a more effective anti-angiogenesis molecule than angiostatin

Inhibits the activity of pancreatic RNase

Potent cytokines in stimulating antitumor immunity, which also showed significant inhibitory activity on angiogenesis

Cytokine with antiangiogenic activity via induction of IFN- $\gamma$

Cytokine with antitumor ability including tumor specific apoptosis, anti-angiogenesis, and immunotherapeutic activity

Member of CXC chemokine family, potent immunomodulatory and antiangiogenic activity

Multifunctional cytokines that regulate antiviral, antitumor, and cellular immune responses, potent antiangiogenic properties via inhibition of bFGF Inhibits proliferation, migration, and adhesion of ECs

Inhibits angiogenesis by inhibiting HGF signaling

Inhibits angiogenesis by increasing thrombospondin-1 expression and decreasing VEGF expression

Inhibits angiogenesis through interfering with VEGF signaling

Inhibits ECs proliferation and migration

Inhibits ECs migration, induces apoptosis

Soluble VEGFR-2, inhibiting VEGF signaling passage

Soluble VEGFR-1, inhibiting VEGF signaling passage

Most potent naturally occurring angiostatic steroid

Inhibits ECs proliferation and migration by interactions with CD36

Block the activity of MMPs, inhibits tumor angiogenesis and tumor growth

Potent vessel virulent effects on tumors, inhibits angiogenesis through activity mediated by TNF receptor

Inhibits angiogenesis by binding $\alpha_{v} \beta_{3}$ integrin

Induces EC cell cycle arrest and apoptosis

Induces cell cycle arrest and apoptosis of ECs

Inhibits ECs proliferation, induces tumor cell apoptosis

Suppresses multiple angiogenic signaling pathways by inhibiting endoglin expression

Inhibits VEGF expression

Inhibits VEGFR-2 expression

Suppresses the HGF-induced angiogenesis by inhibiting HGF expression Induces apoptosis within the vascular wall by inhibiting survivin expression

EC, endothelial cell; VEGF, vascular endothelial growth factor; VEGFR, vascular endothelial growth factor receptor; TNF, tumor necrosis factor; IL, interleukin; si, small interfering; CD36, cluster of differentiation 36; HGF, hepatocyte growth factor; HGFK1, hepatocyte growth factor kringle domain 1, bFGF, basic fibroblast growth factor; sFlk1, soluble form of vascular endothelial growth factor receptor 2; sFLT, soluble fms-like tyrosine kinase-1; IFN- $\gamma$, interferon $\gamma ; \mathrm{p} 53$, tumor protein 53. 
results have demonstrated significant anti-tumorigenic effects on prostate cancer cells, indicating that SPTT-MSCs may represent a promising solution for prostate cancer (139). In an additional experiment, gene electrotransfer of naked plasmid DNA containing the tumstatin cDNA has been adopted to investigate the anti-tumor effect of tumstatin in B16F1 melanoma-bearing mice: A marked decrease in tumor growth and an increase in mouse survival was observed, indicating that this strategy appears appealing in terms of gene delivery and tumor suppression (140). In addition, the $\mathrm{pET}-15 \mathrm{~b}$ vector generated to express a synthetic fusion protein, VTF, which is composed of vasostatin and tumstatin with a (Gly-Ser-Gly) $)_{2}$ bridge, demonstrated the suppression of B16 melanoma growth and the potent inhibition of tumor blood vessels formation in vivo, when compared with a single inhibitor, the fusion proteins of different angiogenesis inhibitors targeting different pathways exhibited improved therapeutic effects (141). Additionally, as T42, which was derived from two active domains of tumstatin, has demonstrated anti-tumor efficacy, a previous study constructed two adenoviral vectors with T42 and 4xT42 peptide genes to evaluate their anti-cancer effects on breast cancer in vitro and in vivo; the results suggested evidence that this modality may be a potential alternative for the treatment of breast cancer (142).

Anti-angiogenic metargidin peptide (AMEP). AMEP, the disintegrin domain of human metargidin, is a novel anticancer agent that exerts its effect by binding to $\alpha_{5} \beta_{1}$ and $\alpha_{\mathrm{V}} \beta_{3}$ integrins via its Arg-Gly-Asp (RGD) integrin binding sequence (143-145). The antitumor and anti-angiogenic effects of AMEP were first suggested in vitro using a recombinant protein (143). Subsequently, it was also demonstrated in vivo using an AMEP-coding plasmid (146), and a higher anti-tumor efficiency of AMEP compared with TSP-1 and soluble fms-like tyrosine kinase-1 was observed, with a significant decrease in tumor metastasis, suggesting that AMEP may not only inhibit the proliferation of tumor cells but may also suppress tumor metastasis. Following this, a phase I clinical trial study was conducted to investigate the safety and tolerability of the AMEP plasmid mediated by intratumoral electrotransfer into cutaneous metastatic melanoma. Results indicated a good safety profile and also, to a certain extent, the efficacy of AMEP plasmid gene electrotransfer in metastatic melanoma (147). Additionally, a previous study indicated that the anti-tumor activities of gene electrotransfer of the AMEP plasmid in murine melanoma cells were correlated with the integrin quantity within the melanoma cells, rather than the expression level of AMEP; however, the anti-angiogenic effect was only partly associated with the quantity of integrins, and appeared to be dependent on the dose of the AMEP plasmid (148). In addition, a previous study confirmed that the integrin quantity within melanoma cells may serve as a biomarker for the antitumor efficacy of therapies targeting integrins, whereas the anti-angiogenic effectiveness of the AMEP plasmid may be predicted by the expression levels of AMEP in the treatment of melanoma (149). It also suggested that intratumoral delivery of the AMEP plasmid was more effective compared with an intramuscular method. Based on these aforementioned studies, it may be predicted that future studies investigating the electrotransfer of the AMEP plasmid will be more focused on particular types of cancer, in which the overexpression of integrin is observed.

NK4. First isolated as a proteolytic digestion product of hepatocyte growth factor (HGF) (150), NK4 is a novel anti-tumor agent through its bifunctional activities of HGF antagonism and anti-angiogenesis. Studies have also demonstrated that NK4 exerts potent anti-angiogenic action via indirectly inhibiting VEGF expression of tumor cells concomitant with direct effects on endothelial cells (151). Although the marked anti-angiogenic effect and anti-tumor ability of NK4 has been confirmed in a diverse number of cancer models, such as malignant pleural mesothelioma, melanoma, lung and pancreatic carcinomas, and colon, biliary gastric and gall bladder cancers (152-156), this individual anti-angiogenic agent alone is not therapeutically sufficient, due to the fact that human cancers are more intricate, and require treatment with multiple targets. Therefore, subsequent studies have explored the potential of NK4 in combination with conventional chemotherapeutic agents or with other inhibitors targeting different signaling pathways. Matsumoto et al (157) identified that the anti-tumor efficacy of combining the NK4 plasmid with cisplatin to treat squamous cell carcinomas was increased compared with NK4 gene therapy alone. An additional study demonstrated that 5-fluorouracil enhanced the NK4-induced apoptosis of colon cancer cells by downregulating the intracellular signaling of the HGF/c-Met pathway (158). Previously, studies have explored a more efficient and suitable way to deliver NK4. Zhu et al (159) demonstrated that MSC-based NK4 gene therapy may markedly inhibit the growth of gastric cancer xenografts, and MSCs are a better vehicle for NK4 gene therapy compared with lentiviral vectors. Additionally, a preliminary clinical trial in humans has been designed to examine the safety and possible clinical benefits of adenoviruses expressing NK4 (160).

Endoglin. Endoglin, a TGF- $\beta$ co-receptor, is involved in the activation of a complex signaling pathway regarding the proliferation, migration and adhesion of endothelial cells $(161,162)$, particularly in tumor vasculature, due to the fact that the expression of endoglin is markedly increased in the endothelial cells of tumor vessels, making it a potential predictive factor for tumor prognosis (163). As such, endoglin has been hypothesized to serve as a promising target for cancer therapy, and several studies using different anti-endoglin antibodies, including monoclonal antibodies $(164,165)$, immunotoxin-conjugated antibodies (166) or radiolabeled antibodies (167) have all demonstrated good anti-angiogenic and antitumor responses. In the case of gene therapy, silencing endoglin by RNA interference is considered to be an alternative potential approach for endoglin targeting, and one study group have conducted a series of experiments to explore the potential of this approach. Dolinsek et al (168) first investigated the therapeutic effectiveness of small interfering RNA (siRNA) molecules against endoglin in vitro and in vivo, and the results indicated that siRNA molecules targeting endoglin exhibited good anti-angiogenic and antitumor efficacy 
on endothelial cells in vitro, and on tumors in vivo. However, as the effect of siRNA against endoglin exhibited a short half-life a plasmid DNA encoding shRNA against endoglin was constructed and delivered into murine endothelial cells in vitro and tumors in vivo using gene electrotransfer to determine its antitumor and vascular-targeted effects (169). Furthermore, in order to specifically silence endoglin within the tumor vasculature, the same study group also prepared a plasmid that silenced endoglin with a tissue-specific promoter (hTERT) (170), which was endothelin-1-dependent and was involved in migration of endothelial cells (171). The results of the study indicated that this plasmid may achieve higher levels of specificity and safety with the same efficacy as a plasmid with a constitutive promoter. An additional previous study demonstrated that endothelial and melanoma cells expressed high levels of endoglin, and that subsequent to endoglin silencing with gene electrotransfer, cell viability was specifically decreased; whereas in tumor cells with low expression of endoglin, only a non-specific decrease in cell viability was observed following electrotransfer (172), providing novel possibilities for melanoma treatment with targeted gene therapy approach.

\section{Conclusion and future direction}

The previous 4 decades have witnessed the feasibility of Folkman's theory in cancer treatment. Anti-angiogenesis therapy, which used to be described as a novel and potential method waiting to be verified of its efficacy in treatment of various diseases, particularly cancer, now represents one of the most significant and promising treatment modalities in clinical oncology. With numerous efforts exploring the various possibilities in utilizing anti-angiogenesis therapy, gene therapy has become an attractive alternative to conventional protein drugs due to its ability to achieve prolonged and localized gene expression, without the issues of high cost and complex processes of production associated with protein drugs.

With increased interest in angiogenesis during the previous two decades, studies examining gene-based anti-angiogenic approaches have made progress in the following three aspects. Firstly, there has been continuous identification of targets for anti-angiogenic gene therapy due to the additional understanding of tumor angiogenesis. Secondly, further improving the efficacy of existing gene delivery systems, with detailed optimization, including the use of tissue-specific promoters or peptides specifically targeted to tumor ECs, and exploring novel methods to better facilitate gene transfer, particularly in the field of non-viral delivery method, such as ultrasound and gene electrotransfer. Thirdly, constantly improving anti-tumor efficacy by combining anti-angiogenic genes with other genes, including different angiogenesis or suicide genes, or genes that neutralize anti-angiogenic resistance such as antisense HIF-1 $\alpha$. As an increasing number of studies have identified that using the anti-angiogenic gene approach as a monotherapy is not sufficient for tumor eradication, and that certain angiogenesis inhibitors may make tumor cells more susceptible towards chemotherapy and radiotherapy, subsequent studies have investigated anti-angiogenic gene therapy in combination with chemotherapy or radiotherapy.
Although a number of individual angiogenesis inhibitors have demonstrated the ability to suppress tumor progression and metastasis in a variety of cancer models, the efficacy of tumor regression varies between different types of cancer when using the same angiogenesis inhibitor, indicating that a future direction for anti-angiogenic gene therapy is to identify prognostic biomarkers to assist in determining the most efficient angiogenesis inhibitor gene for each type of cancer, which will largely rely on an improved understanding of the biological mechanisms of tumor angiogenesis. In addition, as anti-angiogenic gene therapy has demonstrated more potent effectiveness in small tumors compared with large ones, future application of anti-angiogenic gene therapy may be more involved in preventing and treating early-stage cancers. Notably, the methods of gene delivery and the limited therapeutic effect of monotherapy are major obstacles to anti-angiogenic gene therapy; therefore, efforts to develop more efficient gene delivery methods, and to explore additional possibilities in combination therapy, are required. Furthermore, a better understanding of the mechanisms of action and a better selection of the clinical trial patient population should also be performed by future studies.

\section{Acknowledgements}

Not applicable.

\section{Funding}

The present study was supported by the National Nature Science Foundation of China (grant no. 31470967).

\section{Availability of data and materials}

Not applicable.

\section{Authors' contributions}

$\mathrm{HH}$ gave guidance on the conception and design of the article. TL and GK contributed their ideas on this topic and were involved in planning the structure of this review. GK and TW participated in the collection and organization. TL was a major contributor in writing the review. HH made critical modifications to important knowledge content within the manuscript. GK was a major contributor in revision of the manuscript. All authors read and approved the final manuscript.

\section{Ethics approval and consent to participate}

Not applicable.

\section{Consent for publication}

Not applicable.

\section{Competing interests}

The authors declare that they have no competing interests. 


\section{References}

1. Hanahan D and Folkman J: Patterns and emerging mechanisms of the angiogenic switch during tumorigenesis. Cell 86: 353-364, 1996.

2. Fan TP, Jaggar R and Bicknell R: Controlling the vasculature: Angiogenesis, anti-angiogenesis and vascular targeting of gene therapy. Trends Pharmacol Sci 16: 57-66, 1995.

3. Folkman J and Shing Y: Angiogenesis. J Biol Chem 267: 10931-10934, 1992.

4. Folkman J: Tumor angiogenesis: Therapeutic implications. N Engl J Med 285: 1182-1186, 1971.

5. Folkman J: Anti-angiogenesis: New concept for therapy of solid tumors. Ann Surg 175: 409-416, 1972.

6. Dimova I, Popivanov G and Djonov V: Angiogenesis in cancer-general pathways and their therapeutic implications. J BUON 19: 15-21, 2014.

7. Ribatti D, Nico B, Crivellato E, Roccaro AM and Vacca A: The history of the angiogenic switch concept. Leukemia 21: 44-52, 2007.

8. Welti J, Loges S, Dimmeler S and Carmeliet P: Recent molecular discoveries in angiogenesis and antiangiogenic therapies in cancer. J Clin Invest 123: 3190-3200, 2013.

9. Ribatti D and Djonov V: Intussusceptive microvascular growth in tumors. Cancer Lett 316: 126-131, 2012.

10. Donnem T, Hu J, Ferguson M, Adighibe O, Snell C, Harris AL, Gatter KC and Pezzella F: Vessel co-option in primary human tumors and metastases: An obstacle to effective anti-angiogenic treatment? Cancer Med 2: 427-436, 2013.

11. de la Puente P, Muz B, Azab F and Azab AK: Cell trafficking of endothelial progenitor cells in tumor progression. Clin Cancer Res 19: 3360-3368, 2013

12. Moschetta M, Mishima Y, Sahin I, Manier S, Glavey S, Vacca A, Roccaro AM and Ghobrial IM: Role of endothelial progenitor cells in cancer progression. Biochim Biophys Acta 1846: 26-39, 2014.

13. Seftor RE, Hess AR, Seftor EA, Kirschmann DA, Hardy KM, Margaryan NV and Hendrix MJ: Tumor cell vasculogenic mimicry: From controversy to therapeutic promise. Am J Pathol 181: 1115-1125, 2012.

14. Ferrara N and Adamis AP: Ten years of anti-vascular endothelial growth factor therapy. Nat Rev Drug Discov 15: 385-403, 2016.

15. Mihicprobst D, Ikenberg K, Tinguely M, Schraml P, Behnke S, Seifert B, Civenni G, Sommer L, Moch H and Dummer R: Tumor cell plasticity and angiogenesis in human melanomas. PLoS One 7: e33571, 2012

16. Liekens S, Schols D and Hatse S: CXCL12-CXCR4 axis in angiogenesis, metastasis and stem cell mobilization. Curr Pharm Des 16: 3903-3920, 2010

17. Eelen G, de Zeeuw P, Simons M and Carmeliet P: Endothelial cell metabolism in normal and diseased vasculature. Circ Res 116: 1231-1244, 2015.

18. Bridgeman VL, Vermeulen PB, Foo S, Bilecz A, Daley F, Kostaras E, Nathan MR, Wan E, Frentzas S, Schweiger T, et al: Vessel co-option is common in human lung metastases and mediates resistance to anti-angiogenic therapy in preclinical lung metastasis models. J Pathol 241: 362-374, 2017.

19. Hlushchuk R, Riesterer O, Baum O, Wood J, Gruber G, Pruschy $\mathrm{M}$ and Djonov V: Tumor recovery by angiogenic switch from sprouting to intussusceptive angiogenesis after treatment with PTK787/ZK222584 or ionizing radiation. Am J Pathol 173: 1173-1185, 2008.

20. Frentzas S, Simoneau E, Bridgeman VL, Vermeulen PB, Foo S, Kostaras E, Nathan M, Wotherspoon A, Gao ZH, Shi Y, et al: Vessel co-option mediates resistance to anti-angiogenic therapy in liver metastases. Nat Med 22: 1294-1302, 2016.

21. Kerbel RS: Tumor angiogenesis: Past, present and the near future Carcinogenesis 21: 505-515, 2000 .

22. Carmeliet P: Developmental biology. Controlling the cellular brakes. Nature 401: 657-658, 1999.

23. Dor Y, Porat R and Keshet E: Vascular endothelial growth factor and vascular adjustments to perturbations in oxygen homeostasis. Am J Physiol Cell Physiol 280: C1367-C1374, 2001

24. Littlepage LE, Sternlicht MD, Rougier N, Phillips J, Gallo E, Yu Y, Williams K, Brenot A, Gordon JI and Werb Z: Matrix metalloproteinases contribute distinct roles in neuroendocrine prostate carcinogenesis, metastasis, and angiogenesis progression. Cancer Res 70: 2224-2234, 2010
25. Carmeliet P, Dor Y, Herbert JM, Fukumura D, Brusselmans K, Dewerchin M, Neeman M, Bono F, Abramovitch R, Maxwell P, et al: Role of HIF-1alpha in hypoxia-mediated apoptosis, cell proliferation and tumour angiogenesis. Nature 394 485-490, 1998

26. Maracle CX and Tas SW: Inhibitors of angiogenesis: Ready for prime time? Best Pract Res Clin Rheumatol 28: 637-649, 2014.

27. Blancas AA, Wong LE, Glaser DE and McCloskey KE: Specialized tip/stalk-like and phalanx-like endothelial cells from embryonic stem cells. Stem Cells Dev 22: 1398-1407, 2013.

28. Jakobsson L, Franco CA, Bentley K, Collins RT, Ponsioen B, Aspalter IM, Rosewell I, Busse M, Thurston G, Medvinsky A, et al: Endothelial cells dynamically compete for the tip cell position during angiogenic sprouting. Nat Cell Biol 12: 943-953, 2010.

29. Lobov IB, Renard RA, Papadopoulos N, Gale NW, Thurston G, Yancopoulos GD and Wiegand SJ: Delta-like ligand 4 (Dll4) is induced by VEGF as a negative regulator of angiogenic sprouting. Proc Natl Acad Sci USA 104: 3219-3224, 2007.

30. Liu Z, Fan F, Wang A, Zheng S and Lu Y: Dll4-Notch signaling in regulation of tumor angiogenesis. J Cancer Res Clin Oncol 140: 525-536, 2014

31. Pandya NM, Dhalla NS and Santani DD: Angiogenesis-a new target for future therapy. Vasc Pharmacol 44: 265-274, 2006.

32. Bergers $G$ and Song S: The role of pericytes in blood-vessel formation and maintenance. Neuro Oncol 7: 452-464, 2005.

33. Izzedine H, Ederhy S, Goldwasser F, Soria JC, Milano G, Cohen A, Khayat D and Spano JP: Management of hypertension in angiogenesis inhibitor-treated patients. Ann Oncol 20: 807-815, 2009

34. Liu SX, Xia ZS and Zhong YQ: Genetic therapy in pancreatic cancer. World J Gastroenterol 20: 13343-13368, 2014.

35. Edelstein ML, Abedi MR, Wixon J and Edelstein RM: Gene therapy clinical trials worldwide 1989-2004-an overview. J Gene Med 6: 597-602, 2004.

36. Edelstein ML, Abedi MR and Wixon J: Gene therapy clinical trials worldwide to 2007-an update. J Gene Med 9: 833-842, 2007.

37. Ginn SL, Alexander IE, Edelstein ML, Abedi MR and Wixon J: Gene therapy clinical trials worldwide to 2012-an update. J Gene Med 15: 65-77, 2013

38. Ortiz R, Melguizo C, Prados J, Álvarez PJ, Caba O, Rodríguez-Serrano F, Hita F and Aránega A: New gene therapy strategies for cancer treatment: A review of recent patents. Recent Pat Anticancer Drug Discov 7: 297-312, 2012

39. Cao S, Cripps A and Wei MQ: New strategies for cancer gene therapy: progress and opportunities. Clin Exp Pharmacol Physiol 37: 108-114, 2010.

40. Tseng SJ, Liao ZX, Kao SH, Zeng YF, Huang KY, Li HJ, Yang CL, Deng YF, Huang CF, Yang SC, et al: Highly specific in vivo gene delivery for $\mathrm{p} 53$-mediated apoptosis and genetic photodynamic therapies of tumour. Nat Commun 6: 6456, 2015.

41. Gogiraju R, Steinbrecher JH, Lehnart SE, Kessel M, Dobbelstein $\mathrm{M}$ and Schaefer K: Importance of tumor suppressor gene p53-mediated endothelial cell apoptosis for cardiac angiogenesis and hypertrophy. Eur Heart J 34 (Suppl 1): S1616, 2013.

42. Tazawa H, Kagawa $\mathrm{S}$ and Fujiwara T: Advances in adenovirus-mediated p53 cancer gene therapy. Expert Opin Biol Ther 13: 1569-1583, 2013.

43. Prabha S, Sharma B and Labhasetwar V: Inhibition of tumor angiogenesis and growth by nanoparticle-mediated p53 gene therapy in mice. Cancer Gene Ther 19: 530-537, 2012

44. Teodoro JG, Evans SK and Green MR: Inhibition of tumor angiogenesis by p53: A new role for the guardian of the genome. J Mol Med (Berl) 85: 1175-1186, 2007.

45. Zhang $\mathrm{C}$, Wang QT, Liu $\mathrm{H}$, Zhang $\mathrm{ZZ}$ and Huang WL: Advancement and prospects of tumor gene therapy. Chin J Cancer 30: 182-188, 2011

46. El-Aneed A: An overview of current delivery systems in cancer gene therapy. J Control Release 94: 1-14, 2004.

47. Ramsey JD, Vu HN and Pack DW: A top-down approach for construction of hybrid polymer-virus gene delivery vectors. J Control Release 144: 39-45, 2010.

48. Lundstrom K: Alphavirus vectors as tools in neuroscience and gene therapy. Virus Res 216: 16-25, 2016.

49. LU Y, Yan M, Chen IS and Liang M: Viral vector nanocapsule for targeting gene therapy and its preparation. Journal, 2015.

50. Touchefeu Y, Harrington KJ, Galmiche JP and Vassaux G: Review article: Gene therapy, recent developments and future prospects in gastrointestinal oncology. Aliment Pharmacol Ther 32: 953-968, 2010 
51. Liao ZK, Tsai KC, Wang HT, Tseng SH, Deng WP, Chen WS and Hwang LH: Sonoporation-mediated anti-angiogenic gene transfer into muscle effectively regresses distant orthotopic tumors. Cancer Gene Ther 19: 171-180, 2012.

52. Ren J, Zhang P, Tian J, Zhou Z, Liu X, Wang D and Wang Z: A targeted ultrasound contrast agent carrying gene and cell-penetrating peptide: Preparation and gene transfection in vitro. Colloids Surf B Biointerfaces 121: 362-370, 2014.

53. Yarmush ML, Golberg A, Serša G, Kotnik T and Miklavčič D: Electroporation-based technologies for medicine: principles, applications, and challenges. Annu Rev Biomed Eng 16: 295-320, 2014.

54. Wang W, Li W, Ma N and Steinhoff G: Non-viral gene delivery methods. Curr Pharm Biotechnol 14: 46-60, 2013.

55. Audouy SA, de Leij LF, Hoekstra D and Molema G: In vivo characteristics of cationic liposomes as delivery vectors for gene therapy. Pharm Res 19: 1599-1605, 2002.

56. Hortobagyi GN, Ueno NT, Xia W, Zhang S, Wolf JK, Putnam JB, Weiden PL, Willey JS, Carey M, Branham DL, et al: Cationic liposome-mediated E1A gene transfer to human breast and ovarian cancer cells and its biologic effects: A phase i clinical trial. J Clin Oncol 19: 3422-3433, 2001.

57. Wakabayashi T, Natsume A, Mizuno M, Fujii M, Shimato S and Yoshida J: A clinical trial of cationic liposomes containing interferon-b gene for patients with malignant glioma. Int Conf Brain Tumor Res Ther, pp225-225, 2009.

58. Wang Y, Gao S, Ye WH, Yoon HS and Yang YY: Co-delivery of drugs and DNA from cationic core-shell nanoparticles self-assembled from a biodegradable copolymer. Nat Mater 5: 791-796, 2006.

59. Power AT and Bell JC: Cell-based delivery of oncolytic viruses: A new strategic alliance for a biological strike against cancer Mol Ther 15: 660-665, 2007.

60. Muta M, Matsumoto G, Hiruma K, Nakashima E and Toi M: Study of cancer gene therapy using IL-12-secreting endothelial progenitor cells in a rat solid tumor model. Oncol Rep 10 1765-1769, 2003.

61. Yin H, Kanasty RL, Eltoukhy AA, Vegas AJ, Dorkin JR and Anderson DG: Non-viral vectors for gene-based therapy. Nat Rev Genet 15: 541-555, 2014.

62. Kim WJ, Yockman JW, Lee M, Jeong JH, Kim YH and Kim SW: Soluble Flt-1 gene delivery using PEI-g-PEG-RGD conjugate for anti-angiogenesis. J Control Release 106: 224-234, 2005.

63. Persano L, Crescenzi M and Indraccolo S: Anti-angiogenic gene therapy of cancer: Current status and future prospects. Mol Aspects Med 28: 87-114, 2007.

64. Albini A, Tosetti F, Li VW, Noonan DM and Li WW: Cancer prevention by targeting angiogenesis. Nat Rev Clin Oncol 9 : 498-509, 2012.

65. Morrison C: $\$ 1-$ million price tag set for Glybera gene therapy. Nat Biotechnol 33: 217-218, 2015.

66. Rodriguez D and Miessner P: Production of AAV vectors for gene therapy: A cost-effectiveness and risk assessment (unpublished $\mathrm{PhD}$ thesis). Department of Chemical Engineering and the MIT Sloan School of Management, 2016.

67. Chen HH, Kuliszewski MA, Rudenko D and Leong-Poi H: Pre-clinical evaluation of pro-angiogenic gene therapy by ultrasound-targeted microbubble destruction of vascular endothelial growth factor minicircle dna in an model of severe peripheral arterial disease in watanabe heritable hyperlipidemic rabbits. Can J Cardiol 31 (Suppl): S282, 2015.

68. Feng X: Angiogenesis and Antiangiogenesis Therapies: Spear and Shield of Pharmacotherapy. J Pharma Care Health Sys 1: e110, 2014.

69. Ichihara E, Kiura $\mathrm{K}$ and Tanimoto M: Targeting angiogenesis in cancer therapy. Acta Med Okayama 65: 353-362, 2011.

70. Trinchieri G: Interleukin-12: A cytokine produced by antigen-presenting cells with immunoregulatory functions in the generation of T-helper cells type 1 and cytotoxic lymphocytes. Blood 84: 4008-4027, 1994.

71. Trinchieri G: Interleukin-12: A proinflammatory cytokine with immunoregulatory functions that bridge innate resistance and antigen-specific adaptive immunity. Annu Rev Immunol 13 251-276, 1995.

72. Duda DG, Sunamura M, Lozonschi L, Kodama T, Egawa S, Matsumoto G, Shimamura H, Shibuya K, Takeda K and Matsuno S: Direct in vitro evidence and in vivo analysis of the antiangiogenesis effects of interleukin 12. Cancer Res 60: 1111-1116, 2000.

73. Dias S, Boyd R and Balkwill F: IL-12 regulates VEGF and MMPs in a murine breast cancer model. Int J Cancer 78: 361-365, 1998.
74. Voest EE, Kenyon BM, O'Reilly MS, Truitt G, D'Amato RJ and Folkman J: Inhibition of angiogenesis in vivo by interleukin 12 . J Natl Cancer Inst 87: 581-586, 1995.

75. Akiyama Y, Maruyama K, Watanabe M and Yamaguchi K: Retroviral-mediated IL-12 gene transduction into human CD34+ cell-derived dendritic cells. Int J Oncol 21: 509-514, 2002.

76. Sunamura M, Sun L, Lozonschi L, Duda DG, Kodama T, Matsumoto G, Shimamura H, Takeda K, Kobari M, Hamada H and Matsuno S: The antiangiogenesis effect of interleukin 12 during early growth of human pancreatic cancer in SCID mice. Pancreas 20: 227-233, 2000.

77. Li Q, Zhihua W, Xiumin Y, et al: The effect of il-12 on the proliferation in vitro and anti-tumor effects of cik cells in vivo and in vitro. J Pract Oncol 21: 212-215, 2007. (In Chinese)

78. Nguyen K, Koppolu B, Smith G, Ravindranathan S and Zaharoff D: Interleukin-12 elicits various responses of splenocytes from different mouse strains. J Immunol 194 (1 Suppl): S49.8, 2015.

79. Portielje JE, Kruit WH, Schuler M, Beck J, Lamers CH, Stoter G, Huber C, de Boer-Dennert M, Rakhit A, Bolhuis RL and Aulitzky WE: Phase I study of subcutaneously administered recombinant human interleukin 12 in patients with advanced renal cell cancer. Clin Cancer Res 5: 3983-3989, 1999.

80. Gollob JA, Mier JW, Veenstra K, McDermott DF, Clancy D, Clancy $M$ and Atkins MB: Phase I trial of twice-weekly intravenous interleukin 12 in patients with metastatic renal cell cancer or malignant melanoma: Ability to maintain IFN-gamma induction is associated with clinical response. Clin Cancer Res 6: $1678-1692,2000$

81. Hurteau JA, Blessing JA, DeCesare SL and Creasman WT: Evaluation of recombinant human interleukin-12 in patients with recurrent or refractory ovarian cancer: A gynecologic oncology group study. Gynecol Oncol 82: 7-10, 2001.

82. Daud A, Takamura KT, Diep T, Heller R and Pierce RH: Long-term overall survival from a phase I trial using intratumoral plasmid interleukin-12 with electroporation in patients with melanoma. J Transl Med 13 (Suppl 1): O3, 2015.

83. Daud A, Algazi A, Ashworth M, Buljan M, Takamura, KT, Diep T, Pierce RH and Bhatia S: Intratumoral electroporation of plasmid interleukin-12: Efficacy and biomarker analyses from a phase 2 study in melanoma (OMS-I100). J Transl Med 13 (Suppl 1): O11, 2015.

84. Cutrera J, King G, Jones P, Kicenuik K, Gumpel E, Xia X and Li S: Safety and Efficacy of Tumor-Targeted Interleukin 12 Gene Therapy in Treated and Non-Treated, Metastatic Lesions. Curr Gene Ther 15: 44-55, 2014.

85. Lampreht U, Kamensek U, Stimac M, et al: Gene electrotransfer of canine interleukin 12 into canine melanoma cell lines. J Membr Biol 248: 909-917, 2015.

86. Markert JM, Cody JJ, Parker JN, Coleman JM, Price KH, Kern ER, Quenelle DC, Lakeman AD, Schoeb TR, Palmer CA, et al: Preclinical evaluation of a genetically engineered herpes simplex virus expressing interleukin-12. J Virol 86: 5304-5313, 2012.

87. Kramer MG, Masner M, Casales E, Moreno M, Smerdou C and Chabalgoity JA: Neoadjuvant administration of Semliki Forest virus expressing interleukin-12 combined with attenuated Salmonella eradicates breast cancer metastasis and achieves long-term survival in immunocompetent mice. BMC Cancer 15: 620,2015

88. Koneru M, O'Cearbhaill R, Pendharkar S, Spriggs DR and Brentjens RJ: A phase I clinical trial of adoptive T cell therapy using IL-12 secreting MUC-16(ecto) directed chimeric antigen receptors for recurrent ovarian cance. J Transl Med 13: 102, 2015.

89. Poutou J, Bunuales M, Gonzalez-Aparicio M, Garcia-Aragoncillo E, Quetglas JI, Casado R, Bravo-Perez C, Alzuguren P and Hernandez-Alcoceba R: Safety and antitumor effect of oncolytic and helper-dependent adenoviruses expressing interleukin-12 variants in a hamster pancreatic cancer model. Gene Ther 22: 696-706, 2015.

90. Li Y, Li X, Liu H, Zhuang S, Yang J and Zhang F: Intranasal immunization with recombinant Lactococci carrying human papillomavirus E7 protein and mouse interleukin-12 DNA induces E7-specific antitumor effects in C57BL/6 mice. Oncol Lett 7: 576-582, 2014.

91. Freytag SO, Zhang Y and Siddiqui F: Preclinical toxicology of oncolytic adenovirus-mediated cytotoxic and interleukin-12 gene therapy for prostate cancer. Mol Ther Oncolytics 2: pii: $15006,2015$. 
92. Cutrera J, King G, Jones P, Kicenuik K, Gumpel E, Xia X and Li S: Safe and effective treatment of spontaneous neoplasms with interleukin 12 electro-chemo-gene therapy. J Cell Mol Med 19: 664-675, 2015.

93. Jiang H, Lin JJ, Su Z, Goldstein N and Fisher P: Subtraction hybridization identifies a novel melanoma differentiation associated gene, mda-7, modulated during human melanoma differentiation, growth and progression. Oncogene 11: 2477-2486, 1995

94. Jiang H, Su ZZ, Lin JJ, Goldstein NI, Young CS and Fisher PB: The melanoma differentiation associated gene mda-7 suppresses cancer cell growth. Proc Natl Acad Sci USA 93: 9160-9165, 1996

95. Su ZZ, Madireddi MT, Lin JJ, Young CS, Kitada S, Reed JC, Goldstein NI and Fisher PB: The cancer growth suppressor gene mda-7 selectively induces apoptosis in human breast cancer cells and inhibits tumor growth in nude mice. Proc Natl Acad Sci USA 95: 14400-14405, 1998.

96. Saeki T, Mhashilkar A, Swanson X, Zou-Yang XH, Sieger K, Kawabe S, Branch CD, Zumstein L, Meyn RE, Roth JA, et al Inhibition of human lung cancer growth following adenovirus-mediated mda-7 gene expression in vivo. Oncogene 21 : 4558-4566, 2002

97. Sauane M, Gopalkrishnan RV, Lebedeva I, Mei MX, Sarkar D, Su ZZ, Kang DC, Dent P, Pestka S and Fisher PB: Mda-7/IL-24 induces apoptosis of diverse cancer cell lines through JAK/STAT-independent pathways. J Cell Physiol 196: 334-345, 2003.

98. Menezes ME, Shen XN, Das SK, Emdad L, Guo C, Yuan F, Li YJ, Archer MC, Zacksenhaus E, Windle JJ, et al: MDA-7/IL-24 functions as a tumor suppressor gene in vivo in transgenic mouse models of breast cancer. Oncotarget 6: 36928-36942. 2015.

99. Li YJ, Liu G, Xia L, Xiao X, Liu JC, Menezes ME, Das SK, Emdad L, Sarkar D, Fisher PB, et al: Suppression of Her2/Neu mammary tumor development in mda-7/IL-24 transgenic mice. Oncotarget 6: 36943-36954, 2015.

100. Chen X, Liu D, Wang J, Su Q, Zhou P, Liu J, Luan M and Xu X: Suppression effect of recombinant adenovirus vector containing hIL-24 on Hep-2 laryngeal carcinoma cells. Oncol Lett 7 : 771-777, 2014

101. Liu Z, Xu L, Yuan H, Zhang Y, Zhang X and Zhao D: Oncolytic adenovirus-mediated mda-7/IL-24 expression suppresses osteosarcoma growth and enhances sensitivity to doxorubicin. Mo Med Rep 12: 6358-6364, 2015.

102. Khodadad M, Hosseini SY, Shenavar F, Erfani N, Bina S, Ahmadian S, Fattahi MR and Hajhosseini R: Construction of expressing vectors including melanoma differentiation-associated gene-7 (mda-7) fused with the RGD sequences for better tumor targeting. Iran J Basic Med Sci 18: 780-787, 2015

103. O'Reilly MS, Holmgren L, Shing Y, Chen C, Rosenthal RA, Moses M, Lane WS, Cao Y, Sage EH and Folkman J: Angiostatin: A novel angiogenesis inhibitor that mediates the suppression of metastases by a Lewis lung carcinoma. Cell 79: 315-328, 1994.

104. Wahl ML, Moser TL and Pizzo SV: Angiostatin and anti-angiogenic therapy in human disease. Recent Prog Horm Res 59: 73-104, 2004.

105. Zhang G, Jin G, Nie X, Mi R, Zhu G, Jia W and Liu F: Enhanced antitumor efficacy of an oncolytic herpes simplex virus expressing an endostatin-angiostatin fusion gene in human glioblastoma stem cell xenografts. PLoS One 9 e95872, 2014

106.Zhu G, Su W, Jin G, Xu F, Hao S, Guan F, Jia W and Liu F: Glioma stem cells targeted by oncolytic virus carrying endostatin-angiostatin fusion gene and the expression of its exogenous gene in vitro. Brain Res 1390: 59-69, 2011.

107. Tysome JR, Wang P, Alusi G, Briat A, Gangeswaran R, Wang J, Bhakta V, Fodor I, Lemoine NR and Wang Y: Lister vaccine strain of vaccinia virus armed with the endostatin-angiostatin fusion gene: An oncolytic virus superior to d11520 (ONYX-015) for human head and neck cancer. Hum Gene Ther 22: 1101-1108, 2011.

108. Hutzen B, Bid HK, Houghton PJ, Pierson CR, Powell K, Bratasz A, Raffel C and Studebaker AW: Treatment of medulloblastoma with oncolytic measles viruses expressing the angiogenesis inhibitors endostatin and angiostatin. BMC Cancer 14: 206, 2014.

109. Li X, Liu YH, Lee SJ, Gardner TA, Jeng MH and Kao C: Prostate-restricted replicative adenovirus expressing human endostatin-angiostatin fusion gene exhibiting dramatic antitumor efficacy. Clin Cancer Res 14: 291-299, 2008.
110. Ma HI, Lin SZ, Chiang YH, Li J, Chen SL, Tsao YP and Xiao X Intratumoral gene therapy of malignant brain tumor in a rat model with angiostatin delivered by adeno-associated viral (AAV) vector. Gene Ther 9: 2-11, 2002.

111. Li R, Chen H and Ren CS: Growth inhibition of breast cancer in rat by AAV mediated angiostatin gene. Chin J Cancer Res 19: 108-112, 2007.

112. Kubo S, Takagi-Kimura M and Kasahara N: Combinatorial anti-angiogenic gene therapy in a human malignant mesothelioma model. Oncol Rep 34: 633-638, 2015.

113. Tan JF, Lu Q, Zhang XW and Tan M: Effect of co-transfection of angiostatin and Fas gene on growth of transplanted tumor in nude mice. China J Mod Med 8: 013, 2008 (In Chinese).

114. Kim HS, Jeong HY, Lee YK, Kim KS and Park YS: Synergistic antitumoral effect of IL-12 gene cotransfected with antiangiogenic genes for Angiostatin, Endostatin, and Saxatilin. Oncol Res Featuring Preclinical Clin Cancer Ther 21: 209-216, 2013.

115. Sun X, Vale M, Jiang X, Gupta R and Krissansen G: Antisense HIF-1alpha prevents acquired tumor resistance to angiostatin gene therapy. Cancer Gene Ther 17: 532-540, 2010.

116. Chen XJ, Zhu YY, Hu ZT, Zhang HH. Weng SM and Zhuang HZ: Effect of co-transfection of p53 and angiostatin gene on the apoptosis of gastric cancer SG7901 cells. Tumor 7: 577-580, 2010.

117. Schmitz V, Tirado-Ledo L, Raskopf E, Rabe C, Wernert N, Wang L, Prieto J, Qian C, Sauerbruch T and Caselmann WH Effective antitumour mono- and combination therapy by gene delivery of angiostatin-like molecule and interleukin-12 in a murine hepatoma model. Int J Colorectal Dis 20: 494-501, 2005.

118. Kuo CH, Chang BI, Lee FT, Chen PK, Lee JS, Shi GY and Wu HL: Development of recombinant adeno-associated virus serotype 2/8 carrying kringle domains of human plasminogen for sustained expression and cancer therapy. Hum Gene Ther 26: 603-613, 2015

119. Chu Y, Liu H, Lou G, Zhang Q and Wu C: Human placenta mesenchymal stem cells expressing exogenous kringle1-5 protein by fiber-modified adenovirus suppress angiogenesis. Cancer Gene Ther 21: 200-208, 2014.

120. Schmitz V, Sauerbruch T and Raskopf E: Anti-tumoural effects of PlgK1-5 are directly linked to reduced ICAM expression, resulting in hepatoma cell apoptosis. Int J Colorectal Dis 27: 1029-1038, 2012.

121. O'Reilly MS, Boehm T, Shing Y, Fukai N, Vasios G, Lane WS, Flynn E, Birkhead JR, Olsen BR and Folkman J: Endostatin: An endogenous inhibitor of angiogenesis and tumor growth. Cell 88: 277-285, 1997.

122. Sasaki T, Fukai N, Mann K, Göhring W, Olsen BR and Timpl R: Structure, function and tissue forms of the C-terminal globular domain of collagen XVIII containing the angiogenesis inhibitor endostatin. EMBO J 17: 4249-4256, 1998.

123. Rong B, Yang S, Li W, Zhang W and Ming Z: Systematic review and meta-analysis of Endostar (rh-endostatin) combined with chemotherapy versus chemotherapy alone for treating advanced non-small cell lung cancer. World J Surg Oncol 10: 170, 2012.

124. Huiqi G, Jing Z, Peng F, Yong L and Baozhong S: In vivo study of the effect of combining endostatin gene therapy with 32P-colloid on hepatocarcinoma and its functioning mechanism. J BUON 20: 1042-1047, 2015.

125. Yan F, Zheng Y and Huang L: Adenovirus-mediated combined anti-angiogenic and pro-apoptotic gene therapy enhances antitumor efficacy in hepatocellular carcinoma. Oncol Lett 5 : 348-354, 2013

126. Xu Y, Xie Z, Zhou Y, Zhou X, Li P, Wang Z and Zhang Q: Experimental endostatin-GFP gene transfection into human retinal vascular endothelial cells using ultrasound-targeted cationic microbubble destruction. Mol Vis 21: 930-938, 2015.

127. Li XP, Zhang HL, Wang HJ, Li YX, Li M, Lu L, Wan Y, Zhou BL, Liu Y, Pan Y, et al: Ad-endostatin treatment combined with low-dose irradiation in a murine lung cancer model. Oncol Rep 32: 650-658, 2014.

128. Liu RY, Zhou L, Zhang YL, Huang BJ, Ke ML, Chen JM, Li LX, $\mathrm{Fu} \mathrm{X}, \mathrm{Wu} \mathrm{JX}$ and Huang W: An oncolytic adenovirus enhances antiangiogenic and antitumoral effects of a replication-deficient adenovirus encoding endostatin by rescuing its selective replication in nasopharyngeal carcinoma cells. Biochem Biophys Res Commun 442: 171-176, 2013

129. Li L, Zhang Y, Zhou L, Ke ML, Chen JM, Fu X, Ye CL, Wu JX, Liu RY and Huang W: Antitumor efficacy of a recombinant adenovirus encoding endostatin combined with an E1B55KD-deficient adenovirus in gastric cancer cells. J Transl Med 11: 257, 2013. 
130. Zhou Y, Gu H, Xu Y, Li F, Kuang S, Wang Z, Zhou X, Ma H, $\mathrm{Li} \mathrm{P}$, Zheng Y, et al: Targeted antiangiogenesis gene therapy using targeted cationic microbubbles conjugated with CD105 antibody compared with untargeted cationic and neutral microbubbles. Theranostics 5: 399-417, 2015.

131. Maeshima Y, Colorado PC, Torre A, Holthaus KA, Grunkemeyer JA, Ericksen MB, Hopfer H, Xiao Y, Stillman IE and Kalluri R: Distinct antitumor properties of a type IV collagen domain derived from basement membrane. J Biol Chem 275: 21340-21348, 2000.

132. Yang YP, Xu CX, Hou GS, Xin JX, Wang W and Liu XX: Effects of eukaryotic expression plasmid encoding human tumstatin gene on endothelial cells in vitro. Chin Med J (Engl) 123: 2269-2273, 2010.

133. Borza CM, Pozzi A, Borza DB, Pedchenko V, Hellmark T, Hudson BG and Zent R: Integrin alpha3beta1, a novel receptor for alpha3(IV) noncollagenous domain and a trans-dominant Inhibitor for integrin alphavbeta3. J Biol Chem 281: 20932-20939, 2006.

134. Hwang-Bo J, Park JH and Chung IS: Tumstatin induces apoptosis mediated by Fas signaling pathway in oral squamous cell carcinoma SCC-VII cells. Oncol Lett 10: 1016-1022, 2015.

135. Goto T, Ishikawa H, Matsumoto K, Nishimura D, Kusaba M, Taura N, Shibata H, Miyaaki H, Ichikawa T, Hamasaki K, et al: Tum-1, a tumstatin fragment, gene delivery into hepatocellular carcinoma suppresses tumor growth through inhibiting angiogenesis. Int J Oncol 33: 33-40, 2008

136. You Y, Xue X, Li M, Qin X, Zhang C, Wang W, Giang C, Wu S, Liu Y, Zhu W, et al: Inhibition effect of pcDNA-tum-5 on the growth of S180 tumor. Cytotechnology 56: 97-104, 2008.

137. Caudroy S, Cucherousset J, Lorenzato M, Zahm JM, Martinella-Catusse C, Polette $\mathrm{M}$ and Birembaut P: Implication of tumstatin in tumor progression of human bronchopulmonary carcinomas. Hum Pathol 35: 1218-1222, 2004

138. Yang YP, Xu CX, Hou GS, Xin JX, Wang W and Liu XX: Effects of eukaryotic expression plasmid encoding human tumstatin gene on endothelial cells in vitro. Chin Med J (Engl) 123: 2269-2273, 2010.

139. Zhang X, Xu W, Qian H, Zhu W and Zhang R: Mesenchymal stem cells modified to express lentivirus TNF- $\alpha$ Tumstatin(45-132) inhibit the growth of prostate cancer. J Cell Mol Med 15: 433-444, 2011.

140. Thevenard J, Ramont L, Mir LM, Dupont-Deshorgue A, Maquart FX, Monboisse JC and Brassart-Pasco S: A new anti-tumor strategy based on in vivo tumstatin overexpression after plasmid electrotransfer in muscle. Biochem Biophys Res Commun 432: 549-552, 2013.

141. Gu Q, Sun C, Luo J, Zhang T and Wang L: Inhibition of angiogenesis by a synthetic fusion protein VTF derived from vasostatin and tumstatin. Anticancer Drugs 25: 1044-1051, 2014

142. Zhang X, Qi DD, Zhang TT, Chen QX, Wang GZ, Sui GY, Hao XW, Sun S, Song X and Chen YL: Antitumor activity of adenoviral vector containing T42 and 4xT42 peptide gene through inducing apoptosis of tumor cells and suppressing angiogenesis. Mol Med Rep 11: 2083-2091, 2015.

143. Trochon-Joseph V, Martel-Renoir D, Mir LM, Thomaïdis A, Opolon P, Connault E, Li H, Grenet C, Fauvel-Lafève F, Soria $\mathrm{J}$, et al: Evidence of antiangiogenic and antimetastatic activities of the recombinant disintegrin domain of metargidin. Cancer Res 64: 2062-2069, 2004.

144. Nath D, Slocombe PM, Stephens PE, Warn A, Hutchinson GR, Yamada KM, Docherty AJ and Murphy G: Interaction of metargidin (ADAM-15) with alphavbeta3 and alpha5beta1 integrins on different haemopoietic cells. J Cell Sci 112: 579-587, 1999.

145. Danhier F, Le Breton A and Préat V: RGD-based strategies to target alpha(v) beta(3) integrin in cancer therapy and diagnosis. Mol Pharm 9: 2961-2973, 2012.

146. Daugimont L, Vandermeulen G, Defresne F, Bouzin C, Mir LM, Bouquet C, Feron $\mathrm{O}$ and Préat V: Antitumoral and antimetastatic effect of antiangiogenic plasmids in B16 melanoma: Higher efficiency of the recombinant disintegrin domain of ADAM 15. Eur J Pharm Biopharm 78: 314-319, 2011.

147. Spanggaard I, Snoj M, Cavalcanti A, Bouquet C, Sersa G, Robert C, Cemazar M, Dam E, Vasseur B, Attali P, et al: Gene electrotransfer of plasmid antiangiogenic metargidin peptide (AMEP) in disseminated melanoma: Safety and efficacy results of a phase I first-in-man study. Hum Gene Ther Clin Dev 24: 99-107, 2013.
148. Bosnjak M, Prosen L, Dolinsek T, Blagus T, Markelc B, Cemazar M, Bouquet C and Sersa G: Biological properties of melanoma and endothelial cells after plasmid AMEP gene electrotransfer depend on integrin quantity on cells. J Membr Biol 246: 803-819, 2013.

149. Bosnjak M, Dolinsek T, Cemazar M, Kranjc S, Blagus T, Markelc B, Stimac M, Zavrsnik J, Kamensek U, Heller L, et al: Gene electrotransfer of plasmid AMEP, an integrin-targeted therapy, has antitumor and antiangiogenic action in murine B16 melanoma. Gene Ther 22: 578-590, 2015.

150. Date K, Matsumoto K, Shimura H, Tanaka M and Nakamura T: $\mathrm{HGF} / \mathrm{NK} 4$ is a specific antagonist for pleiotrophic actions of hepatocyte growth factor. FEBS Lett 420: 1-6, 1997.

151. Kubota T, Matsumura A, Taiyoh H, Izumiya Y, Fujiwara H, Okamoto K, Ichikawa D, Shiozaki A, Komatsu S, Nakanishi M, et al: Interruption of the HGF paracrine loop by NK4, an HGF antagonist, reduces VEGF expression of CT26 cells. Oncol Rep 30: 567-572, 2013.

152. Kishi Y, Kuba K, Nakamura T, Wen J, Suzuki Y, Mizuno S, Nukiwa T, Matsumoto K and Nakamura T: Systemic NK4 gene therapy inhibits tumor growth and metastasis of melanoma and lung carcinoma in syngeneic mouse tumor models. Cancer Sci 100: 1351-1358, 2009.

153. Ogura Y, Mizumoto K, Nagai E, Murakami M, Inadome N, Saimura M, Matsumoto K, Nakamura T, Maemondo M, Nukiwa T and Tanaka M: Peritumoral injection of adenovirus vector expressing NK4 combined with gemcitabine treatment suppresses growth and metastasis of human pancreatic cancer cells implanted orthotopically in nude mice and prolongs survival. Cancer Gene Ther 13: 520-529, 2006.

154. Nakamura T, Sakai K, Nakamura T and Matsumoto K: Anti-cancer approach with NK4: Bivalent action and mechanisms. Anticancer Agents Med Chem 10: 36-46, 2010.

155. Matsumoto K and Nakamura T: Mechanisms and significance of bifunctional NK4 in cancer treatment. Biochem Biophys Res Commun 333: 316-327, 2005.

156. Suzuki Y, Sakai K, Ueki J, Xu Q, Nakamura T, Shimada H, Nakamura $\mathrm{T}$ and Matsumoto $\mathrm{K}$ : Inhibition of Met/HGF receptor and angiogenesis by NK4 leads to suppression of tumor growth and migration in malignant pleural mesothelioma. Int $\mathbf{J}$ Cancer 127: 1948-1957, 2010.

157. Matsumoto G, Omi Y, Lee U, Kubota E and Tabata Y: NK4 gene therapy combined with cisplatin inhibits tumour growth and metastasis of squamous cell carcinoma. Anticancer Res 31: 105-111, 2011.

158. Taiyoh H, Kubota T, Fujiwara H, Matsumura A, Murayama Y, Okamoto K, Ichikawa D, Ochiai T, Nakamura $T$, Matsumoto K, et al: NK4 gene expression enhances 5-fluorouracil-induced apoptosis of murine colon cancer cells Anticancer Res 31: 2217-2224, 2011.

159. Zhu Y, Cheng M, Yang Z, Zeng CY, Chen J, Xie Y, Luo SW, Zhang KH, Zhou SF and Lu NH: Mesenchymal stem cell-based NK4 gene therapy in nude mice bearing gastric cancer xenografts. Drug Des Devel Ther 8: 2449-2462, 2014.

160. Tada Y, Hiroshima K, Shimada H, Morishita N, Shirakawa T, Matsumoto K, Shingyoji M, Sekine I, Tatsumi K and Tagawa M: A clinical protocol to inhibit the HGF/c-Met pathway for malignant mesothelioma with an intrapleural injection of adenoviruses expressing the NK4 gene. Springerplus 4: 358, 2015.

161. Lebrin F, Goumans MJ, Jonker L, Carvalho RL, Valdimarsdottir G, Thorikay M, Mummery C, Arthur HM and ten Dijke P: Endoglin promotes endothelial cell proliferation and TGF-beta/ALK1 signal transduction. EMBO J 23: 4018-4028, 2004

162. Ten Dijke P, Goumans MJ and Pardali E: Endoglin in angiogenesis and vascular diseases. Angiogenesis 11: 79-89, 2008.

163. Nassiri F, Cusimano MD, Scheithauer BW, Rotondo F, Fazio A Yousef GM, Syro LV, Kovacs K and Lloyd RV: Endoglin (CD105): A review of its role in angiogenesis and tumor diagnosis, progression and therapy. Anticancer Res 31: 2283-2290, 2011.

164. Tsujie M, Tsujie T, Toi H, Uneda S, Shiozaki K, Tsai H and Seon BK: Anti-tumor activity of an anti-endoglin monoclonal antibody is enhanced in immunocompetent mice. Int $\mathrm{J}$ Cancer 122: 2266-2273, 2008.

165. Uneda S, Toi H, Tsujie T, Tsujie M, Harada N, Tsai H and Seon BK: Anti-endoglin monoclonal antibodies are effective for suppressing metastasis and the primary tumors by targeting tumor vasculature. Int J Cancer 125: 1446-1453, 2009. 
166. Muñoz R, Arias Y, Ferreras JM, Jiménez P, Langa C Rojo MA, Gayoso MJ, Córdoba-Díaz D, Bernabéu C and Girbés T: In vitro and in vivo effects of an anti-mouse endoglin (CD105)-immunotoxin on the early stages of mouse B16MEL4A5 melanoma tumours. Cancer Immunol Immunother 62: 541-551, 2013.

167. Tabata M, Kondo M, Haruta Y and Seon BK: Antiangiogenic radioimmunotherapy of human solid tumors in SCID mice using (125)I-labeled anti-endoglin monoclonal antibodies. Int J Cancer 82: 737-742, 1999.

168. Dolinsek T, Markelc B, Sersa G, Coer A, Stimac M, Lavrencak J, Brozic A, Kranjc S and Cemazar M: Multiple delivery of siRNA against endoglin into murine mammary adenocarcinoma prevents angiogenesis and delays tumor growth. PLoS One 8: e58723, 2013.

169. Dolinsek T, Markelc B, Bosnjak M, Blagus T, Prosen L, Kranjc S, Stimac M, Lampreht U, Sersa G and Cemazar M: Endoglin silencing has significant antitumor effect on murine mammary adenocarcinoma mediated by vascular targeted effect. Curr Gene Ther 15: 228-244, 2015.

170. Xu Y, Hou J, Liu Z, Yu H, Sun W, Xiong J, Liao Z, Zhou F, Xie $C$ and Zhou Y: Gene therapy with tumor-specific promoter mediated suicide gene plus IL-12 gene enhanced tumor inhibition and prolonged host survival in a murine model of Lewis lung carcinoma. J Transl Med 9: 39, 2011.

171. Stimac M, Dolinsek T, Lampreht U, Cemazar M and Sersa G Gene electrotransfer of plasmid with tissue specific promoter encoding shRNA against endoglin exerts antitumor efficacy against murine TS/A tumors by vascular targeted effects. PLoS One 10: e0124913, 2015.

172. Dolinsek T, Sersa G and Cemazar M: Melanoma cell viability is reduced after endoglin silencing with gene electrotransfer. Biol Med Food Environ Technol: 325-328, 2016

173. Pujade-Lauraine E, Hilpert F, Weber B, et al: Bevacizumab combined with chemotherapy for platinum-resistant recurrent ovarian cancer: the AURELIA open-label randomized phase III trial. J Clin Oncol 32: 1302-1308, 2014.

174. Heinemann V, von Weikersthal LF, Decker T, Kiani A, Vehling-Kaiser U, Al-Batran SE, Heintges T, Lerchenmüller C, Kahl C, Seipelt G, et al: FOLFIRI plus cetuximab versus FOLFIRI plus bevacizumab as first-line treatment for patients with metastatic colorectal cancer (FIRE-3): A randomised, open-label, phase 3 trial. Lancet Oncol 15: 1065-1075, 2014.

175. Rini BI, Bellmunt J, Clancy J, Wang K, Niethammer AG, Hariharan S and Escudier B: Randomized phase III trial of temsirolimus and bevacizumab versus interferon alfa and bevacizumab in metastatic renal cell carcinoma: INTORACT trial. J Clin Oncol 32: 752-759, 2014.

176. Bear HD, Tang G, Rastogi P, Geyer CE Jr, Liu Q, Robidoux A Baez-Diaz L, Brufsky AM, Mehta RS, Fehrenbacher L, et al: Neoadjuvant plus adjuvant bevacizumab in early breast cancer (NSABP B-40 [NRG Oncology]): Secondary outcomes of a phase 3, randomised controlled trial. Lancet Oncol 16: 1037-1048, 2015.

177. Van Cutsem E, Tabernero J, Lakomy R, Prenen H, Prausová J, Macarulla T, Ruff P, van Hazel GA, Moiseyenko V, Ferry D, et al: Addition of aflibercept to fluorouracil, leucovorin, and irinotecan improves survival in a phase III randomized trial in patients with metastatic colorectal cancer previously treated with an oxaliplatin-based regimen. J Clin Oncol 30: 3499-3450, 2012.

178. Tannock IF, Fizazi K, Ivanov S, Karlsson CT, Fléchon A, Skoneczna I, Orlandi F, Gravis G, Matveev V, Bavbek S, et al: Aflibercept versus placebo in combination with docetaxel and prednisone for treatment of men with metastatic castration-resistant prostate cancer (VENICE): A phase 3, double-blind randomised trial. Lancet Oncol 14: 760-768, 2013

179. Ramlau R, Gorbunova V, Ciuleanu TE, Novello S, Ozguroglu M, Goksel T, Baldotto C, Bennouna J, Shepherd FA, Le-Guennec S, et al: Aflibercept and docetaxel versus docetaxel alone after platinum failure in patients with advanced or metastatic non-small-cell lung cancer: A randomized, controlled phase III trial. J Clin Oncol 30: 3640-3647, 2012.

180. Allen JW, Moon J, Redman M, Gadgeel SM, Kelly K, Mack PC Saba HM, Mohamed MK, Jahanzeb M and Gandara DR: Southwest oncology group S0802: A randomized, phase II trial of weekly topotecan with and without ziv-aflibercept in patients with platinum-treated small-cell lung cancer. J Clin Oncol 32: 2463-2470, 2014
181. Siu LL, Shapiro JD, Jonker DJ, Karapetis CS, Zalcberg JR, Simes J, Couture F, Moore MJ, Price TJ, Siddiqui J, et al: Phase III randomized, placebo-controlled study of cetuximab plus brivanib alaninate versus cetuximab plus placebo in patients with metastatic, chemotherapy-refractory, wild-type K-RAS colorectal carcinoma: The NCIC clinical trials group and AGITG CO. 20 trial. J Clin Oncol 31: 2477-2484, 2013.

182. Lordick F, Kang YK, Chung HC, Salman P, Oh SC, Bodoky G, Kurteva G, Volovat C, Moiseyenko VM, Gorbunova V, et al: Capecitabine and cisplatin with or without cetuximab for patients with previously untreated advanced gastric cancer (EXPAND): A randomised, open-label phase 3 trial. Lancet Oncol 14: 490-499, 2013.

183. Hitre E, Budai B, Takácsi-Nagy Z, Rubovszky G, Tóth E, Remenár É, Polgár C and Láng I: Cetuximab and platinum-based chemoradio- or chemotherapy of patients with epidermal growth factor receptor expressing adenoid cystic carcinoma: A phase II trial. Br J Cancer 109: 1117-1122, 2013.

184. Massarelli E, Haddad RI, Lee JJ, Garden AS, Blumenschein GR, William WN, Tisshler RB, Glisson BS, Gold KA, Johnson FM, et al: Randomized phase II trial of weekly paclitaxel, carboplatin, cetuximab (PCC) versus cetuximab, docetaxel, cisplatin, and fluorouracil (C-TPF) in previously untreated patients with locally advanced head and neck squamous cell carcinoma. J Clin Oncol 32: TPS6102, 2014.

185. Wang J, Sun Y and Qin S; Endostar Phase IV Study Group: Results of phase IV clinical trial of combining endostar with chemotherapy for treatment of advanced non-small cell lung cancer (NSCLC). J Clin Oncol 28: 7598, 2010.

186. Cui C, Mao L, Chi Z, Si L, Sheng X, Kong Y, Li S, Lian B, Gu K, Tao M, et al: A phase II, randomized, double-blind, placebo-controlled multicenter trial of Endostar in patients with metastatic melanoma. Mol Ther 21: 1456-1463, 2013.

187. Jin T, Li B and Chen XZ: AA phase II trial of Endostar combined with gemcitabine and cisplatin chemotherapy in patients with metastatic nasopharyngeal carcinoma (NCT01612286). Oncol Res 21: 317-323, 2013.

188. Chen Z, Guo W, Cao J, Lv F, Zhang W, Qiu L, Li W, Ji D, Zhang S, Xia Z, et al: Endostar in combination with modified FOLFOX6 as an initial therapy in advanced colorectal cancer patients: A phase I clinical trial. Cancer Chemother Pharmacol 75: 547-557, 2015.

189. Zhu AX, Rosmorduc O, Evans TJ, Ross PJ, Santoro A, Carrilho FJ, Bruix J, Qin S, Thuluvath PJ, Llovet JM, et al: SEARCH: A phase III, randomized, double-blind, placebo-controlled trial of sorafenib plus erlotinib in patients with advanced hepatocellular carcinoma. J Clin Oncol 33: 559-566, 2015.

190. Brose MS, Nutting CM, Jarzab B, Elisei R, Siena S, Bastholt L, de la Fouchardiere C, Pacini F, Paschke R, Shong YK, et al: Sorafenib in radioactive iodine-refractory, locally advanced or metastatic differentiated thyroid cancer: A randomised, double-blind, phase 3 trial trial. Lancet 384: 319-328, 2014

191. Bruix J, Takayama T, Mazzaferro V, Chau GY, Yang J, Kudo M, Cai J, Poon RT, Han KH, Tak WY, et al: STORM: A phase III randomized, double-blind, placebo-controlled trial of adjuvant sorafenib after resection or ablation to prevent recurrence of hepatocellular carcinoma (HCC). J Clin Oncol 32: 4006, 2014.

192. Schwandt A, von Gruenigen VE, Wenham RM, Frasure H, Eaton S, Fusco N, Fu P, Wright JJ, Dowlati A and Waggoner S: Randomized phase II trial of sorafenib alone or in combination with carboplatin/paclitaxel in women with recurrent platinum sensitive epithelial ovarian, peritoneal, or fallopian tube cancer. Invest New Drugs 32: 729-738, 2014.

193. Motzer RJ, Hutson TE, Tomczak P, Tomczak P, Michaelson M, Bukowski RM, Rixe O, Oudard S, Kim ST, Baum CM and Figlin RA: Phase III randomized trial of sunitinib malate (SU11248) versus interferon-alfa (IFN-\{alpha\}) as first-line systemic therapy for patients with metastatic renal cell carcinoma (mRCC). J Clin Oncol 24: LBA3, 2006.

194. Socinski MA, Novello S, Brahmer JR, Rosell R, Sanchez JM, Belani CP, Govindan R, Atkins JN, Gillenwater HH, Pallares C, et al: Multicenter, phase II trial of sunitinib in previously treated, advanced non-small-cell lung cance. J Clin Oncol 26: 650-656, 2008.

195. Cheng A, Kang Y, Lin D, Park J, Kudo M, Qin S, Omata M, Lowenthal SWP, Lanzalone, S, Yang L, et al: Phase III trial of sunitinib (Su) versus sorafenib (So) in advanced hepatocellular carcinoma (HCC). J Clin Oncol 29: 4000, 2011. 
196. Michaelson MD, Oudard S, Ou YC, Sengeløv L, Saad F, Houede N, Ostler P, Stenzl A, Daugaard G, Jones R, et al: Randomized, placebo-controlled, phase III trial of sunitinib plus prednisone versus prednisone alone in progressive, metastatic, castration-resistant prostate cancer. J Clin Oncol 32: 76-82, 2014

197. Kantarjian HM, Shah NP, Cortes JE, Baccarani M, Agarwal MB, Undurraga MS, Wang J, Ipiña JJ, Kim DW, Ogura M, et al: Dasatinib or imatinib in newly diagnosed chronic-phase chronic myeloid leukemia: 2-year follow-up from a randomized phase 3 trial (DASISION). Blood 119: 1123-1129, 2012

198. Kluger HM, Dudek AZ, McCann C, Ritacco J, Southard N, Jilaveanu LB, Molinaro A and Sznol M: A phase 2 trial of dasatinib in advanced melanoma. Cancer 117: 2202-2208, 2011.

199. Wong SJ, Karrison T, Hayes DN, Kies MS, Cullen KJ, Tanvetyanon T, Argiris A, Takebe N, Lim D, Saba NF, et al: Phase II trial of dasatinib for recurrent or metastatic c-KIT expressing adenoid cystic carcinoma and for nonadenoid cystic malignant salivary tumors. Ann Oncol 27: 318-123, 2016.

200. Herbst RS, Giaccone G, Schiller JH, Natale RB, Miller V, Manegold C, Scagliotti G, Rosell R, Oliff I, Reeves JA, et al: Gefitinib in combination with paclitaxel and carboplatin in advanced non-small-cell lung cancer: a phase III trial-INTACT 2. J Clin Oncol 22: 785-794, 2004

201. Argiris A, Ghebremichael M, Gilbert J, Lee JW, Sachidanandam K, Kolesar JM, Burtness B and Forastiere AA: Phase III randomized, placebo-controlled trial of docetaxel with or without gefitinib in recurrent or metastatic head and neck cancer: An eastern cooperative oncology group trial. J Clin Oncol 31: 1405-1414, 2013.

202.Dutton SJ, Ferry DR, Blazeby JM, Abbas H, Dahle-Smith A, Mansoor W, Thompson J, Harrison M, Chatterjee A, Falk S, et al: Gefitinib for oesophageal cancer progressing after chemotherapy (COG): A phase 3, multicentre, double-blind, placebo-controlled randomised tria. Lancet Oncol 15: 894-904, 2014.
203. Moore MJ, Goldstein D, Hamm J, Figer A, Hecht JR, Gallinger S, Au HJ, Murawa P, Walde D, Wolff RA, et al: Erlotinib plus gemcitabine compared with gemcitabine alone in patients with advanced pancreatic cancer: A phase III trial of the national cancer institute of canada clinical trials group. J Clin Oncol 25: 1960-1966, 2007.

204.Rosell R, Carcereny E, Gervais R, Vergnenegre A, Massuti B, Felip E, Palmero R, Garcia-Gomez R, Pallares C, Sanchez JM, et al: Erlotinib versus standard chemotherapy as first-line treatment for European patients with advanced EGFR mutation-positive non-small-cell lung cancer (EURTAC): A multicentre, open-label, randomised phase 3 trial. Lancet Oncol 13: 239-246, 2012.

205. Sternberg CN, Davis ID, Mardiak J, Szczylik C, Lee E, Wagstaff J, Barrios CH, Salman P, Gladkov OA, Kavina A, et al: Pazopanib in locally advanced or metastatic renal cell carcinoma: results of a randomized phase III trial. J Clin Oncol 28: 1061-1068, 2010.

206. van der Graaf WT, Blay JY, Chawla SP, Kim DW, Bui-Nguyen B, Casali PG, Schöffski P, Aglietta M, Staddon AP, Beppu Y, et al Pazopanib for metastatic soft-tissue sarcoma (PALETTE): A randomised, double-blind, placebo-controlled phase 3 trial. Lancet 379: 1879-1886, 2012.

cc) (i) $\ominus$ This work is licensed under a Creative Commons International (CC BY-NC-ND 4.0) License. 